\title{
KRONIEK
}

\section{Kroniek Rechtspraak Tuchtrecht}

\author{
Mr. C.A. Bol, prof. mr. J.C.J. Dute $\mathcal{E}$ mr. W.R. Kastelein ${ }^{*}$
}

\section{Inleiding}

In deze achtste kroniek Rechtspraak Tuchtrecht die in het TvGR wordt gepubliceerd, worden in grote lijnen dezelfde onderwerpen behandeld als in de vorige kroniek. Het gaat dan om uitspraken over ontvankelijkheid en aanverwante procesrechtelijke onderwerpen, vraagstukken rond ouderlijk gezag, samenwerkingsproblemen, voorbehouden handelingen, dossiervoering en rapporten en verklaringen, alsmede de (zwaarte van) de door tuchtcolleges opgelegde tuchtmaatregelen.

Uit het Jaarverslag Tuchtcolleges voor de Gezondheidszorg 2016 blijkt dat het aantal tuchtklachten redelijk stabiel blijft. De afgelopen vijf jaar schommelde het aantal ingediende tuchtklachten tussen de 1572 en 1646 op een totaal van circa 350.000 BIGgeregistreerden. Het aantal door de Inspectie voor de Gezondheidszorg ingediende klachten lijkt enigszins af te nemen. In 2012 klaagde de Inspectie nog zesendertig keer terwijl dit in 2016 zevenentwintig keer geschiedde. De doorlooptijd van het aantal afgehandelde klachten is dalende. Betrof deze in 2012 nog 287 dagen gemiddeld, in 2016 gaat het om 216 dagen gemiddeld. Gezien het streven van de tuchtcolleges om de doorlooptijden te versnellen, zal dit aantal dagen in 2017 naar verwachting verder dalen. Uit het jaarverslag blijkt dat het de ambitie is van de tuchtcolleges om de doorlooptijd voor zaken

* Caressa Bol is docent en promovenda Gezondheidsrecht aan de Faculteit der Rechtsgeleerdheid, Radboud Universiteit te Nijmegen. Jos Dute is hoogleraar Gezondheidsrecht aan de Faculteit der Rechtsgeleerdheid, Radboud Universiteit te Nijmegen, lid van het College voor de Rechten van de Mens en redacteur van dit tijdschrift. Willemien Kastelein is advocaat/ compagnon Nysingh advocaten-notarissen te Zwolle/Utrecht, en hoofdredacteur van dit tijdschrift. van de Regionale Tuchtcolleges (RTG) terug te brengen tot 180 dagen en voor zaken van het Centraal Tuchtcollege (CTG) tot 270 dagen. Niet duidelijk is overigens waarom het CTG 90 dagen meer nodig zou hebben om tot een beslissing te komen dan een RTG.

Vrijwel alle uitspraken van de tuchtcolleges zijn integraal op internet te vinden. De auteurs van deze kroniek hebben zo veel mogelijk de voor de rechtsontwikkeling interessante uitspraken in deze kroniek verwerkt over de periode van 1 september 2015 tot 1 september 2017. ${ }^{1}$ Daarbij is prioriteit gegeven aan die onderwerpen die in een significant aantal zaken tot tuchtrechtelijke beslissingen hebben geleid.

\section{Ontvankelijkheid en overige procesrechtelijke vraagstukken}

Ook in deze verslagperiode waren er vele klachten en klagers bij wie de ontvankelijkheid ter discussie stond, met name ten aanzien van de vraag of de zogenoemde tweede tuchtnorm, zoals geformuleerd in artikel 47 lid 1 onder b Wet BIG, in het geding was.

In dit tijdschrift is in 2016 een uitvoerig artikel over dit aspect van ontvankelijkheid verschenen. ${ }^{2}$ In dit artikel is de jurisprudentie ten aanzien van dit aspect van ontvankelijkheid betrokken tot en met decem-

1 Sommige uitspraken worden pas later gepubliceerd. Daarom komen ook uitspraken van vóór 1 september 2015 een enkele keer pas in deze kroniek aan de orde.

2 Zie C.A. Bol en J.C.J. Dute, 'Het tuchtrecht voor de beroepen in de individuele gezondheidszorg: de betekenis van de tweede tuchtnorm voor de ontvankelijkheid', TvGR 2016, nr. 5, p. 288 t/m 329. 
ber 2015. Voor zover de daar besproken jurisprudentie in deze verslagperiode valt, zal die jurisprudentie hier niet herhaald worden. Op de bevindingen van het artikel zal zo veel mogelijk worden aangesloten.

\subsection{Klachten van collegae tegen collegae}

In deze verslagperiode is wederom een beperkt aantal klachten van BIG-registreerden tegen een collega-BIG-geregistreerde aan de orde geweest. Eén zaak is echter om verschillende redenen interessant. Het betreft de klacht van een psychiater tegen de hoofdredacteur van het Geneesmiddelenbulletin. De psychiater verweet deze hoofdredacteur (tevens arts en zich afficherend als arts-epidemioloog), dat hij zich in een artikel en in een televisie-uitzending van Brandpunt onjuist en negatief zou hebben uitgelaten over psychiaters en de behandeling van ADHD. Volgens de klagende psychiater zou dit onrust hebben veroorzaakt onder zijn patiënten. De verwerende hoofdredacteur stelde zich op het standpunt dat klager niet-ontvankelijk zou zijn, omdat de klachten zouden moeten worden voorgelegd aan de Raad voor de Journalistiek, hij niet als arts zou hebben gehandeld maar als hoofdredacteur en het Geneesmiddelenbulletin zich zou richten op een specifieke doelgroep, namelijk personen die medicatie voorschrijven of afleveren en dat er derhalve geen sprake zou zijn van individuele gezondheidszorg. Zowel het RTG als het CTG achtten klager ontvankelijk, omdat de inhoud van het artikel en het gegeven interview onmiskenbaar een weerslag hebben op de individuele gezondheidszorg in het algemeen en dit derhalve getoetst kan worden aan de tweede tuchtnorm. Klager wordt als rechtstreeks belanghebbende aangemerkt op basis van zijn stelling dat het artikel en de bijdrage van verweerder aan de televisie-uitzending onrust heeft veroorzaakt onder zijn patiënten en hun kinderen, alsook onder artsen. ${ }^{3}$ Ook interessant is het oordeel van het CTG van 25 augustus $2016^{4}$ waar het ging om een klacht van een cardioloog tegen een andere cardioloog die als arbi-

3 CTG 16 maart 2017, ECLI:NL:TGZCTG:2017:95.

4 ECLI:NL:TGZCTG:2016:277. ter was opgetreden in een geschil dat de klagende cardioloog had met zijn maatschap cardiologie over zijn re-integratie na ziekte. Het College in eerste aanleg verklaarde klager niet-ontvankelijk omdat de klacht betrekking had op werkzaamheden van verweerder in zijn hoedanigheid van arbiter en niet in zijn hoedanigheid van arts.

In hoger beroep oordeelt het CTG dat het door arbiters gegeven oordeel een beslissing is op de door klager als eisende partij in de arbitrale procedure aan arbiters voorgelegde rechtsvraag naar de onrechtmatigheid van het handelen van zijn maten en dat dit rechtsoordeel niet tevens een eigen medisch-inhoudelijke beoordeling van de belastbaarheid of van beperkingen van klager inhoudt. Gelet daarop, aldus het CTG, kan niet worden gezegd dat het oordeel van het arbitrale college waarvan de cardioloog als arbiter deel uitmaakte enige weerslag heeft op de individuele gezondheidszorg. Van handelen in strijd met artikel 47 lid 1 aanhef en onder b Wet BIG is derhalve geen sprake en het feit dat de cardioloog BIG-geregistreerd is maakt dit niet anders. Het CTG handhaaft derhalve het oordeel dat klager niet-ontvankelijk is.

Op 16 mei 2017 ten slotte deed RTG Amsterdam uitspraak in een enigszins curieuze zaak waarin de formele klaagster een patiënt was, van wie de echtgenoot als gemachtigde optrad, tevens voormalig medisch specialist in het betreffende ziekenhuis. De klacht was gericht tegen (het dagelijks bestuur van) een maatschap cardiologie in de personen van drie cardiologen die werd verweten om redenen van gemakzucht de meerdaagse cardiologische zorg te willen verplaatsen naar één locatie. Het Tuchtcollege oordeelde dat klaagster was aan te merken als rechtstreeks belanghebbende ingevolge artikel 65 lid 1 onder a Wet BIG, nu zij heeft gesteld als gevolg van het vermeende handelen van verweerders (het verplaatsen van de meerdaagse klinische cardiologische zorg naar één locatie) als patiënt negatieve gevolgen daarvan te ondervinden. Klaagster had haar klacht blijkens haar klaagschrift gericht tegen het dagelijkse bestuur van de organisatorische eenheid cardiologie, waarvan verweerders deel uitmaken. In artikel 47 lid 1 onder a en b Wet BIG is 
bepaald dat de zorgverlener in zijn hoedanigheid, in dit geval als cardioloog, is onderworpen aan tuchtrechtspraak. Het tuchtrecht gaat daarmee uit van persoonlijke verwijtbaarheid en ziet alleen op handelen door natuurlijke personen en niet door besturen of maatschappen. Voor zover de klacht dus gericht is tegen de eenheid cardiologie, is de klacht niet-ontvankelijk, aldus het College. Het College is op grond van de stukken van oordeel dat niet is gebleken dat tussen verweerders en klaagster sprake was van een behandelrelatie in de zin van artikel 47 lid 1 onder a Wet BIG. Toetsing aan de eerste tuchtnorm is daardoor niet aan de orde. Bij de toetsing aan de tweede tuchtnorm stelt het College vast dat het voorgenomen besluit van verweerders waartegen klaagster ageert ziet op het verplaatsen van de meerdaagse cardiologische zorg van de locatie te I naar de locatie te E bij hoog-risico cardiologische zorg waarbij een (invasieve) diagnostische en/of therapeutische interventie of complexe beeldvorming noodzakelijk is. Voor routinecontroles respectievelijk acute cardiale problemen kunnen patiënten ook in de toekomst terecht bij de polikliniek respectievelijk afdeling SEH op de locatie te I, aldus verweerders. De beleidskeuze van verweerders is voortgekomen uit de wens om een zo goed mogelijke kwaliteit van zorg (veilig en verantwoord) te kunnen leveren aan patiënten. Naar het oordeel van het College behoort het handelen van verweerders - de voorgenomen beleidskeuze - tot keuzes in het kader van de bedrijfsvoering waarbij beleidsvrijheid bestaat, ook al kunnen deze keuzes gevolgen hebben voor de individuele gezondheidszorg. Het is ongewenst dat de tuchtrechter dergelijke beleidskeuzes doorkruist. Daarmee kan het handelen ook op die grond niet inhoudelijk door het College worden getoetst. ${ }^{5}$ Het College verpakt deze beslissing in één uitspraak, hetgeen in strijd lijkt met het uitgangspunt dat iedere BIG-geregistreerde individueel getoetst wordt.

\subsection{Ontvankelijkheid: tweede tuchtnorm}

Ook in deze verslagperiode is er een indrukwekkend aantal uitspraken gedaan waarbij de ontvankelijkheid van klagers in het kader van de tweede tuchtnorm ter discussie stond. Uitgangspunt van het CTG is tegenwoordig het zogenoemde weerslagcriterium. Daarnaast gaat het CTG steeds ruimer om met het criterium 'in de hoedanigheid van BIG-geregistreerde'. Zoals ook door Bol en Dute vastgesteld, ontbreekt echter een heldere en consistente lijn mede waardoor steeds weer discussies ontstaan c.q. in stand worden gehouden.

Een voorbeeld hiervan is een beslissing van RTG Amsterdam van 24 november $2015^{6}$ waarin nabestaanden een bestuurder van een ziekenhuis, tevens cardioloog, aanklagen wegens tekortschietend beleid bij de behandeling van hun overleden vader/ echtgenoot. Het ging daarbij o.a. om dossiervoering, patiëntveiligheid, protocollering en het adequaat reageren op incidenten en calamiteiten. De cardioloog voerde een niet-ontvankelijkheidsverweer, eruit bestaande dat de nabestaanden niet klachtgerechtigd zouden zijn omdat zij niet rechtstreeks belanghebbenden zouden zijn en dat hetgeen hem werd verweten tot zijn managementtaken behoort, dat hem te dien aanzien grote beleidsvrijheid toekomt en dat bovendien het hem verwetene niet tevens op het deskundigheidsgebied van een arts en al helemaal niet op het terrein van een cardioloog ligt. Het Tuchtcollege maakt met dit verweer korte metten en stelt dat ook nabestaanden rechtstreeks belanghebbenden zijn, mits van veronderstelde toestemming kan worden uitgegaan. Deze toestemming was echter niet in twijfel getrokken. Voorts waren de klachten zoals door klagers geformuleerd te plaatsen in het kader van de individuele gezondheidszorg en waren klagers daarmee ontvankelijk. Het College verwijst daarbij expliciet naar het zogenoemde weerslagcriterium en de jurisprudentie van het CTG. Het College wijst vervolgens de tegen verweerder ingediende klachten af, omdat niet is gebleken dat verweerder van hetgeen hem verweten werd een persoonlijk verwijt kon worden gemaakt. Hier- 
bij zij opgemerkt dat de behandelend chirurg in deze zaak een berisping opgelegd heeft gekregen en de arts-assistent niet in opleiding (anios) op de SEH en de betrokken anesthesist allebei een waarschuwing. ${ }^{7}$

Een zaak van een iets andere orde betrof het oordeel van het CTG op 7 juni $2016^{8}$ waar het ging om een klacht ingediend tegen een psychiater/geneesheerdirecteur inzake het ondertekenen van een geneeskundige verklaring en de vraag of dat onder de reikwijdte van artikel 47 Wet BIG viel. Het CTG oordeelde dat dit inderdaad het geval was en dat het feit dat dit handelen ook door de civiele rechter wordt beoordeeld niet aan een tuchtrechtelijke toetsing in de weg staat. Het College geeft de psychiater een waarschuwing onder de aantekening dat dit is bedoeld als een zakelijke terechtwijzing zonder het stempel van persoonlijke laakbaarheid op zijn handelen te drukken.

Het CTG oordeelde op 25 juli $2017^{9}$ over de zaak van een homeopathisch werkzame arts die gratis medicatie verstrekte ten behoeve van aids- en/of hiv-patiënten in Kenia waarbij volgens de IGZ de internationale richtlijnen en de Verklaring van Helsinki zouden zijn geschonden. Het Tuchtcollege Amsterdam had de Inspectie in haar klacht ontvankelijk geacht nu deze klacht mede betrekking had op handelingen van verweerder die weliswaar in het buitenland hadden plaatsgevonden, maar volgens vaste tuchtrechtelijke jurisprudentie de werkingssfeer van het tuchtrecht niet zonder meer beperkt wordt door de Nederlandse landsgrenzen; afhankelijk van de omstandigheden van het geval, waaronder de aard en de ernst van het verwijt en de aard van de relatie, kan aan een BIG-geregistreerd beroepsbeoefenaar met succes een verwijt worden gemaakt indien deze tuchtrechtelijk verwijtbaar in het buitenland heeft gehandeld of nagelaten waarbij mede in aanmerking dient te worden genomen of

7 ECLI:NL:TGZRAMS:2015: 106 t/m 109.

8 ECLI:NL:TGZCTG:2016:219.

9 ECLI:NL:TGZCTG:2017:217; zie voor de uitspraak van RTG Amsterdam 20 december 2016 de noot van J.C.J. Dute in GJ 2017/27. het verwijt daadwerkelijk weerslag heeft op de individuele gezondheidszorg.

Een mooi voorbeeld is de uitspraak van het CTG van 1 november $2016^{10}$ waarin een arts tevens eerste geneeskundige/hoofd behandeldienst van een ouderenzorginstelling niet betrokken was bij de behandeling van patiënte waarover werd geklaagd, maar wel in haar functie van hoofd (manager) verantwoordelijk was voor de aansturing en roostering van artsen en paramedici. De arts bepleitte niet-ontvankelijkheid. Het CTG achtte klaagster ontvankelijk, ook al was er geen sprake van een behandelrelatie tussen de arts en klaagster. De arts was echter in haar functie van hoofd (manager) van de behandeldienst van het zorgcentrum hiërarchisch leidinggevende van de artsen en paramedici en was verantwoordelijk voor een voldoende personele bezetting van die beroepsgroepen binnen het aan haar toegekende budget. Voorts had zij meer in het algemeen een adviserende rol ten aanzien van het kwaliteitsbeleid ten opzichte van de managers zorg en de Raad van Bestuur. Naar aanleiding van de gebeurtenissen had zij ook een calamiteitenmelding gedaan bij de Inspectie en een rapportage opgesteld. De klacht van klaagster hing voor een wezenlijk deel samen met deze activiteiten van de arts en leverde een zodanige samenhang en weerslag op de individuele gezondheidszorg op dat op voorhand niet gezegd kon worden dat toetsing aan de tweede tuchtnorm uitgesloten zou zijn en de arts ook was opgetreden in haar hoedanigheid van arts. Onduidelijk blijft in hoeverre nu het weerslagcriterium alleen als voldoende kan worden beschouwd bij de ontvankelijkheidsbeoordeling of in hoeverre er ook sprake moet zijn van optreden in de hoedanigheid van arts.

\subsection{Hoedanigheid BIG-geregistreerde}

Het CTG oordeelde op 20 augustus $2015^{11}$ over een GZ-psycholoog die als gedragskundige deelnam aan het MDO van de Raad voor de Kinderbescherming inzake een omgangsregeling met betrekking tot een

10 ECLI:NL:TGZCTG:2016:316.

11 ECLI:NL:TGZCTG:2015:277. 
minderjarig kind. Het College in eerste aanleg achtte de klacht van de moeder niet-ontvankelijk, omdat de GZ-psycholoog haar werkzaamheden niet had verricht als GZ-psycholoog, maar als gedragskundige. Het CTG achtte klaagster echter wel ontvankelijk nu de bijdrage van de GZ-psycholoog aan het MDO en het daaruit voortvloeiende rapport waarbij de GZ-psycholoog een consulterende en adviserende rol vervulde gelet op de inhoud van het rapport een weerslag heeft op de individuele gezondheidszorg, waardoor klaagster in haar klacht tegen de GZ-psycholoog in die hoedanigheid kan worden ontvangen.

RTG Zwolle oordeelde op 23 augustus $2016^{12}$ dat een klacht tegen een verpleegkundig manager waarbij de manager werd verweten dat hij niet had toegezien op de naleving van het rookbeleid in de instelling, op het waarborgen van een goede luchtkwaliteit, op het al dan niet voorzien van klager van een bureaustoel en het niet tijdig doorsturen van een klachtbrief niet-ontvankelijk was nu verweerder zich bij het hem verweten handelen of nalaten niet had begeven op het terrein waarop hij de deskundigheid bezit behorende bij zijn inschrijving als verpleegkundige in het BIG-register. Het Tuchtcollege overweegt daarbij nadrukkelijk dat in het midden kan blijven of het aan de orde gestelde handelen of nalaten voldoende weerslag had op de individuele gezondheidszorg. Erg consistent is deze jurisprudentie derhalve niet.

\subsection{Rechtstreeks belanghebbende}

Ook in deze verslagperiode zijn diverse uitspraken gedaan over de vraag of klagers, en dan met name familieleden, als rechtstreeks belanghebbend kunnen worden beschouwd in de zin van artikel 65 lid 1 onder a Wet BIG. Interessant in dat verband is een beslissing van het CTG van 3 december $2015 .{ }^{13}$ In die zaak werd een verpleegkundige aangeklaagd door onder andere de dochter van de inmiddels overleden patiënte. Het CTG oordeelde dat het recht van een naaste betrekking om een klacht in te die- nen ten aanzien van de medische behandeling van een overleden patiënt niet berust op een eigen klachtrecht van de naaste betrekking, maar op een klachtrecht dat is afgeleid van de in het algemeen veronderstelde wil van de patiënt met het gevolg dat van belang is of degene die klaagt daardoor die veronderstelde wil van de overleden patiënt uitdrukt. Voorts onderzoekt het CTG in het algemeen niet ambtshalve of de naaste betrekking de wil van de overleden patiënt vertegenwoordigt, behoudens het geval dat er sprake is van bijzondere omstandigheden die aanleiding geven daaraan te twijfelen. In deze casus oordeelde het CTG dat sprake was van dergelijke bijzondere omstandigheden. De stukken in het dossier en het verhandelde ter zitting in onderling verband en samenhang bezien gaven zodanige aanwijzingen dat er gerede twijfel bestond dat klagers met het indienen van hun klacht de wil van de overleden patiënt vertegenwoordigden, dat het College klagers niet-ontvankelijk achtte. Er was tijdens het leven van de patiënt al sprake van een zeer aanzienlijke spanning tussen de dochter enerzijds en behandelaren van patiënte anderzijds. De dochter had bij leven geklaagd bij de Inspectie en bij de Klachtencommissie, maar patiënte had die klachten niet gesteund. In het cliëntdossier was te lezen dat patiënte tevreden was over het wonen in het zorgcentrum en de aan haar verleende zorg. Patiente was wilsbekwaam. De spanningen met de dochter waren zo hoog opgelopen dat zorgverleners met instemming van patiënte een schaduwdossier hadden aangelegd. Voorts hadden klagers op enig moment patiënte uit de zorginstelling willen weghalen en naar huis willen overbrengen. Dit tegen de verklaarde wil van patiënte, hetgeen zelfs tot politie-interventie had geleid. Gezien al deze feiten en omstandigheden kwam het CTG tot het oordeel dat klagers met het voeren van deze procedure niet de wil van de overleden patiënte vertegenwoordigden, zodat zij geen van de wil van patiënte afgeleid klachtrecht hadden. Ook een door klagers overgelegde volmacht mocht hen niet baten, gezien de zeer algemene bewoordingen ervan en hetgeen hierboven is opgemerkt. 
Enigszins curieus is in dit verband de uitspraak van het CTG van 4 februari $2016^{14}$ waarin het ging om een klacht tegen een psychiater ingediend door een vriend van de patiënt die jarenlang met de patiënt had samengewoond. De patiënt had laten weten niet in te stemmen met het indienen van een tuchtklacht. Het RTG had klager om die reden niet-ontvankelijk verklaard. Het CTG neemt dit oordeel over voor zover het betreft de klacht in het kader van de eerste tuchtnorm. Ten aanzien van het beroep van klager op de tweede tuchtnorm acht het College klager echter wel ontvankelijk, omdat de door hem gestelde handelwijze van de psychiater de individuele gezondheidszorg betrof en directe gevolgen heeft gehad voor klager omdat patiënt uit de woning van klager is gehaald waar patiënt toen verbleef. Het lijkt erop dat het CTG artikel 47 lid 1 onder a nr. $3^{\circ}$, waarin is bepaald dat het handelen van een BIG-geregistreerde ten opzichte van naaste betrekkingen eveneens onderworpen is aan tuchtrechtspraak, plaatst in het licht van de interpretatie van artikel 65 lid 1 onder a Wet BIG waarin is bepaald wanneer iemand rechtstreeks belanghebbende is. Helemaal duidelijk is de uitspraak echter niet, waardoor de overwegingen van het College tot verwarring kunnen leiden. De klachten van klager worden overigens afgewezen.

Een bijzonder gecompliceerde zaak betreft de uitspraak van het CTG van 13 juni $2017^{15}$ waarin een ex-echtgenoot van een overleden patiënte een psychiater aanklaagde wegens de schriftelijke verklaring die hij op verzoek van de tweede echtgenoot van patiënte, inmiddels weduwnaar, in het kader van de afwikkeling van een nalatenschap van patiente had opgesteld, welke verklaring door de weduwnaar was gebruikt in een juridische procedure rond de afwikkeling van de nalatenschap. Klager, de ex-echtgenoot, heeft ouderlijk gezag over twee kinderen die uit het huwelijk met de overledene zijn geboren. Beide kinderen wonen ook bij klager. De kinderen waren ten tijde van het indienen van de klacht 17 respectievelijk 15 jaar. Patiënte was door zelfdoding overleden. Het CTG overweegt ten aanzien van de ontvankelijkheid van klager dat, om aangemerkt te worden als rechtstreeks belanghebbende in de zin van artikel 65 lid 1 onder a Wet BIG er aan de zijde van klager sprake dient te zijn van een belang dat kan worden geplaatst in het kader van de individuele gezondheidszorg. Het CTG is van oordeel dat de door de psychiater afgegeven verklaring de twee kinderen van patiënte raakt in een belang dat kan worden geplaatst in het kader van de individuele gezondheidszorg, nu kennisname van de inhoud van deze verklaring hen mogelijk (in)direct emotioneel zou kunnen schaden en dit consequenties zou kunnen hebben voor hun persoonlijk welzijn c.q. hun gezondheid. Klager is hun vader en verzorger met ouderlijk gezag. Hij voerde de tuchtrechtelijke procedure zonder medeweten, instemming of toestemming dan wel machtiging van de kinderen, omdat zij naar zijn mening zouden moeten blijven gevrijwaard van de in de verklaring opgenomen mogelijk schadelijke (medische) informatie over hun moeder.

Het CTG ziet daarin aanleiding om op de algemene regel dat de laatste officiële levensgezel van de overleden patiënte na overlijden bij uitsluiting van de overige naaste betrekkingen klachtgerechtigd is, een uitzondering te maken en ook klager aan te merken als rechtstreeks belanghebbende, omdat onverkorte handhaving van deze eerder genoemde regel tot de onwenselijke consequentie zou leiden dat beide kinderen verstoken zouden blijven van de aan hen op grond van de Wet BIG toekomende rechtsbescherming. Klager werd derhalve ontvankelijk geacht. Op verzoek van beide partijen wordt voorts besloten om de zitting waarop de klachten inhoudelijk zullen worden behandeld met gesloten deuren te laten plaatsvinden.

Opvallend zijn ook de beslissingen van het CTG van 24 november $2016 .{ }^{16}$ In die zaak had een echtgenoot van een demente patiënte een aantal klachten ingediend tegen de klinisch geriater en een tweetal specialisten ouderengeneeskunde die bij de behandeling van zijn vrouw betrokken waren. De echtge- 
noot was bij beschikking van de rechtbank van 18 februari 2011 benoemd tot mentor van patiënte. In juni 2014 had de instelling aan de kantonrechter verzocht om hem te ontslaan uit zijn functie van mentor, omdat een constructieve samenwerking met hem niet mogelijk zou zijn. Bij beschikking van 16 december 2014 heeft de rechtbank met ingang van 1 januari 2015 de echtgenoot ontslagen als mentor van patiënte en per die datum een andere mentor benoemd. Het klaagschrift was door echtgenoot/klager ingediend op 1 december 2014. De mentor had tijdens de tuchtprocedure schriftelijk laten weten dat zij van mening is dat het voeren van allerlei procedures rond patiënte niet in het belang van patiënte is. Het Tuchtcollege in eerste aanleg had daaruit afgeleid dat de mentor niet instemde met (voortzetting van) de klacht van klager en stelde op grond daarvan vast dat klager niet klachtgerechtigd was in de zin van artikel 65 lid 1 onder a Wet BIG en verklaarde hem niet-ontvankelijk. Het CTG overwoog dat in dit geval uit de gedingstukken genoegzaam bleek dat patiënte ten tijde van het indienen van de klacht en het beroep en ook al geruime tijd voordien niet in staat was te communiceren dan wel anderszins haar wil tot uitdrukking te brengen. Voorts was klager wel ten tijde van het indienen van de klacht nog de mentor, maar niet meer ten tijde van het instellen van het beroep en was hij volgens het CTG derhalve ook niet langer bevoegd om in die hoedanigheid namens patiënte het beroep in te stellen. Dat betekent dat beoordeeld moest worden of klager in zijn hoedanigheid van echtgenoot in het beroep ontvangen kan worden. Daarbij geldt als uitgangspunt, aldus het CTG, dat het recht van een naaste betrekking om een klacht in te dienen namens een naaste niet op een eigen klachtrecht berust, maar op het klachtrecht van de veronderstelde wil van de patiënt. Omdat deze patiente niet in staat was haar wil uit te drukken, is op grond van artikel 1:453 lid 2 BW een mentor benoemd. In het algemeen mag ervan worden uitgegaan dat de mentor de veronderstelde wil van de patiënt tot uitdrukking brengt. In een geval als dit waarin klager, oorspronkelijk mentor van patiënt, is ontslagen in het belang van de zorgverlening aan patiënte, is voor ontvankelijkheid van klager in ieder geval vereist dat de mentor van patiënte als haar vertegenwoordiger in rechte instemt met het beroep. $\mathrm{Nu}$ daarvan niet blijkt, is klager niet-ontvankelijk. Het CTG komt dan ook niet toe aan een verdere beoordeling van het beroep en laat in het midden of klager terecht niet-ontvankelijk is verklaard door het RTG. Omdat klager echter niet-ontvankelijk is verklaard in het beroep blijft de beslissing van het RTG, waarin is beslist dat hij niet in de klacht ontvangen kon worden, in stand.

\subsection{Procesrechtelijke perikelen}

In deze verslagperiode zijn er flink wat uitspraken die betrekking hebben op procesrechtelijke vraagstukken. Hierna volgt een selectie van de opvallendste.

Het CTG oordeelde op 21 mei $2015^{17}$ dat in een zaak waarin de klacht gegrond is verklaard zonder oplegging van een maatregel geen hoger beroep openstaat onder verwijzing naar eerdere jurisprudentie (zie ECLI:NL:TGZCTG:2011:YG1550). Het CTG overweegt dat het doel van het tuchtrecht is handhaving van de kwaliteit van de beroepsuitoefening door BIG-geregistreerden. Het beroep staat alleen open voor zover klachten zijn afgewezen. Dit brengt echter niet mee dat het bestaan van een beroepsmogelijkheid tevens zou moeten worden aangenomen in een geval waarin de klacht gegrond is verklaard, doch zonder oplegging van een maatregel. Oplegging van een tuchtrechtelijke maatregel beoogt immers niet zozeer om aan de klager wiens klacht gegrond wordt verklaard genoegdoening te verschaffen als wel om - in het belang van een behoorlijke beroepsuitoefening - de betrokken beroepsbeoefenaar in te scherpen dat hij professioneel beneden de maat is gebleven, aldus het CTG. Een opvallende redenering, nu ditzelfde CTG bij het opleggen van de maatregel van waarschuwing in het algemeen expliciet overweegt dat daaraan het karakter van laakbaarheid ontbreekt. De hier gekozen formulering zou toch anders doen vermoeden.

\section{ECLI:NL:TGZCTG:2015:168.}


Eveneens interessant is een drietal uitspraken van het CTG van 22 december $2015^{18}$ waar het ging om de cardiologen van het Ruwaard van Putten Ziekenhuis te Spijkenisse, aangeklaagd door de Inspectie voor de Gezondheidszorg.

De Inspectie voor de Gezondheidszorg had de drie cardiologen van het Ruwaard van Putten Ziekenhuis aangeklaagd voor het collectieve falen van de maatschap cardiologie ten aanzien van de organisatie van de zorg binnen de maatschap en ten aanzien van tekortkomingen in de cardiologische zorgverlening. Een individuele, directe zorgrelatie had IGZ bewust niet aan haar klacht ten grondslag gelegd en het RTG meende dit ook niet ambtshalve te kunnen onderzoeken nu IGZ daartoe onvoldoende had gesteld. Het ter illustratie overleggen van twaalf patiëntendossiers zonder concrete toelichting en onderbouwing achtte het RTG onvoldoende. Nu deze klacht niet kon vallen onder de reikwijdte van de eerste tuchtnorm onderzocht het RTG ambtshalve of de klacht onder de tweede tuchtnorm zou kunnen vallen. De conclusie was dat de tweede tuchtnorm inderdaad was geschonden, omdat er op onderdelen sprake was geweest van een gebrekkige organisatie en samenwerking in de maatschap cardiologie. Alle drie cardiologen kregen een berisping opgelegd.

In hoger beroep accepteerde het CTG deze redenering van het RTG onder de aantekening dat de cardiologen niet hadden gegriefd tegen de gegrond bevonden klachtonderdelen en de daaraan ten grondslag liggende motivering, waardoor vaststond dat de maatschap cardiologie was tekortgeschoten in de organisatie van de zorg. Evenmin was gegriefd tegen de ambtshalve beoordeling of de tweede tuchtnorm was geschonden. Dit is jammer, omdat het interessant zou zijn geweest hoe het CTG over dergelijke grieven zou hebben geoordeeld. Voor wat betreft de verantwoordelijkheid van de cardiologen overweegt het CTG conform eerdere jurisprudentie dat onder omstandigheden iedere arts binnen een maatschap verantwoordelijk kan worden gehouden voor de praktijkvoering en de daarbinnen verleende gezondheidszorg, maar dat daarvoor ten minste is vereist dat de maatschap zodanig is ingericht dat niet één arts de verantwoordelijkheid draagt voor het beleid ten aanzien van de patiënten. In het onderhavige geval kon van een collectief gedragen verantwoordelijkheid onder de eerste tuchtnorm, zoals door IGZ betoogd, geen sprake zijn nu het aan tal van daarvoor vereiste voorwaarden, zoals goede overdracht, goede onderlinge communicatie en regelmatige patiëntenbespreking, juist ontbrak. De vraag rees vervolgens of IGZ ten aanzien van de op grond van de eerste tuchtnorm geformuleerde subsidiaire klachten wel ontvankelijk was. De subsidiaire klacht ging uit van individuele verantwoordelijkheid van de cardioloog ten aanzien van zijn handelen of nalaten in een of meer van de twaalf door IGZ genoemde patiëntendossiers. De initiële klacht was echter opgezet met het oog op de collectieve verantwoordelijkheid, terwijl het in eerste aanleg aan een deugdelijke onderbouwing per dossier van de subsidiaire klacht had ontbroken. Die was pas in hoger beroep gegeven. Het CTG oordeelde dat de aanpak van IGZ op dit punt allerminst de schoonheidsprijs verdiende, maar dat het in beginsel toelaatbaar is dat IGZ een in eerste aanleg summier geformuleerde klacht in hoger beroep van een nadere onderbouwing voorziet. Er was immers geen sprake van een nieuwe klacht, maar van het alsnog funderen van een eerder geformuleerd klachtonderdeel. Ook het beroep op een goede procesorde slaagde niet, nu de cardioloog in hoger beroep voldoende in de gelegenheid was gesteld verweer te voeren tegen de nadere onderbouwing van de klacht en van die gelegenheid ook gebruik had gemaakt.

Een zaak van geheel andere orde was de beslissing van het CTG van 28 januari 2016. ${ }^{19}$ In die zaak had het RTG de klachten van klaagster afgewezen. Klaagster was in hoger beroep gegaan. Na het indienen van het hoger beroep was klaagster overleden. De arts bepleitte in dat kader niet-ontvankelijkheid in beroep. Het CTG oordeelde dat het overlijden van klaagster ná het indienen van een beroep en nadat de beroepsgronden ter kennis van het CTG waren 
gekomen niet tot gevolg had dat het CTG niet tot een beoordeling van het beroep kon komen of dat de klacht of het beroep van rechtswege als ingetrokken of vervallen zou moeten worden beschouwd. Het overlijden van klaagster stond ontvankelijkheid van het beroep niet in de weg.

In het kader van de ontvankelijkheid is tevens opvallend een beslissing van het CTG van 7 april $2016^{20}$ waarin een klager verblijvend in een penitentiaire inrichting in eerste aanleg niet-ontvankelijk was verklaard, omdat hij, ondanks dat hij verschillende keren daartoe in de gelegenheid was gesteld, niet de namen noemde over wie hij klaagde en zijn klacht richtte tegen de medische dienst van de penitentiaire inrichting. In hoger beroep heeft het CTG de directeur van de penitentiaire inrichting als getuige gehoord. Klager heeft in hoger beroep aangevoerd dat hij klachten heeft tegen diverse artsen die deel uitmaken van de medische dienst van de penitentiaire inrichting, maar dat hij niet bekend is met hun namen. Volgens klager is het in penitentiaire inrichtingen gangbaar om gedetineerden geen achternaam van behandelaars te geven en hooguit de voornaam bekend te maken. De inrichting weigerde hem de volledige namen van deze artsen te verstrekken. Daardoor, aldus klager, wordt hem de mogelijkheid ontnomen gebruik te maken van het recht om een klacht in te dienen tegen een medisch hulpverlener die is ingeschreven in het BIG-register. Ter zitting bleek de directeur van de inrichting de achternamen van de artsen die klager hadden behandeld wel te kunnen noemen, evenals hun voornamen en de data waarop deze artsen klager hadden behandeld. Het CTG concludeert dat, ook al voldeed het klaagschrift niet aan het bepaalde in artikel 4 lid 1 onder c Tuchtrechtbesluit BIG, het RTG op grond van het bepaalde in artikel 66 lid 4 Wet BIG niet tot niet-ontvankelijkverklaring kon beslissen en het in dit specifieke geval op de weg van het RTG had gelegen om nader onderzoek te doen naar de mogelijkheid van klager om alsnog de namen van de artsen te achterhalen. Het CTG vernietigde de niet-ontvankelijkheidsbeslissing van het RTG en verwees de zaak terug, waarbij klager alsnog in de gelegenheid moest worden gesteld om het geconstateerde verzuim, namelijk het ontbreken van de naam van de arts of de artsen over wie hij wilde klagen, te herstellen, waarna het Tuchtcollege in eerste aanleg tot behandeling en beoordeling van de klacht zou kunnen overgaan.

Een enigszins vergelijkbare zaak betrof het oordeel van het CTG op 7 juli 2016. ${ }^{21}$ In die zaak ging het om een klager die volgens RTG Den Haag niet had voldaan aan het verzoek van de vooronderzoeker om te berichten tegen welke beroepsbeoefenaar of beroepsbeoefenaren zijn klacht was gericht en ook geen duidelijke omschrijving had gegeven van de verwijten die hij de aangeklaagde maakte. Het CTG was het daarmee niet eens en oordeelde dat, nu klager de inhoud van zijn klacht en de feiten/gronden waarop zijn klacht berust voldoende duidelijk had weergegeven en de naam van degene over wie werd geklaagd in het klaagschrift had vermeld, voldaan was aan de krachtens artikel 65 lid 2 Wet BIG gestelde eisen. Het CTG deed de zaak nu zelf af met instemming van partijen. Een van de klachten ging over het afgeven van een voorwaardelijke rechterlijke machtiging overeenkomstig de Wet Bopz. Verweerder had bij dit klachtonderdeel een beroep gedaan op niet-ontvankelijkheid, omdat klager civiele rechtsmiddelen ter beschikking staan om de rechterlijke machtiging aan te vechten. Het CTG ging hier niet in mee (zie ook de geneesheer-directeur in $\S 2.2$ ) en stelde dat het openstaan van civiele middelen niet betekent dat het handelen van een BIG-geregistreerde niet ter toetsing (aan andere normen) aan de tuchtrechter kan worden voorgelegd. Overigens werden alle klachten van klager afgewezen.

Een zaak van andere orde is de beslissing van het CTG van 24 november $2016^{22}$ alwaar het CTG een deel van de beslissing van het RTG vernietigt waar het gaat om het oordeel van het RTG dat een klachtonderdeel gegrond is dat niet in het klaagschrift was opgenomen, maar alleen in de daarbij overgelegde

21 ECLI:NL:TGZCTG:2016:288.

22 ECLI:NL:TGZCTG:2016:357. 
stukken. Het CTG stelt vast dat uit het proces-verbaal van de zitting van het RTG niet blijkt dat deze klacht expliciet als een te beoordelen klachtonderdeel aan de orde is gesteld en dat in het algemeen geldt dat in het kader van het recht op hoor en wederhoor en om de arts voldoende in de gelegenheid te stellen zich tegen klachtonderdelen te verweren, slechts kan worden geoordeeld over klachten die zijn opgenomen in het klaagschrift dan wel in een later stadium of uiteindelijk ter zitting expliciet als klachtonderdeel aan de orde zijn gesteld. Het door het RTG ambtshalve beoordeelde klachtonderdeel is niet opgenomen in het klaagschrift van klaagster en is ook niet expliciet als klachtonderdeel besproken met de arts. Beoordeling van het klachtonderdeel en de gegrondverklaring daarvan heeft derhalve ten onrechte plaatsgevonden.

Op 1 december $2016^{23}$ besliste het CTG dat, nu de arts zijn beroep vóór de behandeling ter zitting in hoger beroep had ingetrokken, de Wet BIG niet de mogelijkheid zou bieden de behandeling in beroep om redenen aan het algemeen belang ontleend desgewenst voort te zetten en staakte het CTG de behandeling in beroep. Deze uitspraak gaat uit van een beperkte interpretatie van artikel 73 lid 7 Wet BIG en staat wellicht op gespannen voet met de uitspraak van hetzelfde College, maar in een andere samenstelling, van 24 november 2016, ${ }^{24}$ alwaar klaagster ter zitting in hoger beroep haar klacht introk en de arts geen voortzetting van de behandeling verzocht. In die zaak achtte het CTG geen redenen van algemeen belang aanwezig op grond waarvan de behandeling van de klacht toch zou moeten worden voortgezet en werd de behandeling van de klacht ingevolge het bepaalde in artikel 73 lid 7 jo. artikel 65 lid 10 Wet BIG gestaakt. Het verschil in beide zaken is dat in de eerste zaak de verwerend arts het hoger beroep introk en in de tweede zaak de oorspronkelijke klaagster. Artikel 73 lid 7 Wet BIG bepaalt dat artikel 65 lid 10 in hoger beroep van overeenkomstige toepassing is. Zonder nadere uitleg valt niet in te zien waarom in hoger beroep arti-

23 ECLI:NL:TGZCTG:2016:261.

24 ECLI:NL:TGZCTG:2016:358. kel 65 lid 10 Wet BIG niet zou (kunnen) gelden voor de oorspronkelijk verwerend arts, in hoger beroep appellant, die het hoger beroep intrekt, als het CTG van mening zou zijn dat de behandeling van de klacht om redenen aan het algemeen belang ontleend zou moeten worden voortgezet. Deze vraag is niet alleen van theoretisch belang nu er in de eerste zaak sprake was van ernstige verwijten, waarbij de chirurg de bevoegdheid tot het verrichten van heelkundige handelingen was ontzegd. Indien en voor zover het CTG voortzetting van de behandeling van de zaak van belang had geacht, is het de vraag waarom dat niet mogelijk zou zijn geweest op grond van artikel 73 lid 7 jo. artikel 65 lid $10 \mathrm{Wet}$ BIG.

Als laatste in deze trits van procesrechtelijke perikelen zij genoemd de beslissing van het CTG van 19 januari $2016^{25}$ waarin heimelijk opgenomen bandopnamen een rol speelden. Het College in eerste aanleg had gesteld dat ook als bewijsmateriaal onrechtmatig is verkregen niet als algemene regel geldt dat de rechter daarop geen acht zou mogen slaan, omdat in beginsel het maatschappelijk belang dat partijen erbij hebben hun stellingen in rechte aannemelijk te maken zwaarder weegt dan het belang van uitsluiting van dat (onrechtmatig verkregen) bewijs. Slechts indien sprake is van bijkomende omstandigheden is uitsluiting van dat bewijs gerechtvaardigd, stelt het RTG onder verwijzing naar HR 11 juli 2014. ${ }^{26}$ Van deze bijkomende omstandigheden was in deze zaak, aldus het RTG, niet gebleken. In hoger beroep stelt het CTG zich, zij het met een andere motivering, op hetzelfde standpunt, onder verwijzing naar de beslissing van het CTG van 12 augustus $2014,{ }^{27}$ waarin is bepaald dat ook als het maken van heimelijke bandopnamen onrechtmatig zou zijn dat niet zonder meer leidt tot uitsluiting van dergelijke opnamen als bewijsmiddel in een tuchtzaak op grond van de Wet BIG. In een tuchtprocedure tussen enerzijds nabestaanden en anderzijds een of meer van bij de gesprekken

25 ECLI:NL:TGZCTG:2016:39, GJ 2016/102 m.nt. J.C.J. Dute.

26 ECLI:NL:HR:2014:1632.

27 ECLI:NL:TGZCTG:2014:305. 
betrokken artsen kan de inhoud van zulke heimelijk gemaakte opnamen in beginsel worden gebruikt als bewijs van hetgeen tijdens die gesprekken is gezegd. Het CTG voegt daar nog aan toe dat een patiënt goede redenen kan hebben een gesprek dat hij voert met zijn zorgverlener op te nemen, omdat dat hem in de gelegenheid stelt de inhoud van het gesprek op een later moment nog eens rustig te overdenken. Het getuigt van fatsoen om de betrokken zorgverlener daarover te informeren, maar als dat achterwege wordt gelaten staat dat aan het gebruik van die opname als bewijsmiddel in een tuchtprocedure in beginsel niet in de weg. Overigens valt volgens het CTG ook niet in te zien waarom een gesprek waarvan men weet dat dit door de gesprekspartner wordt opgenomen inhoudelijk anders zou worden gevoerd dan een gesprek waarbij dat niet het geval is. Dit alles bijzondere omstandigheden daargelaten.

\subsection{Reikwijdte tuchtrecht}

Sinds de uitspraak van het CTG van 12 februari 2015 is het vaste jurisprudentie dat handelen in de privésfeer onder de reikwijdte van het tuchtrecht kan vallen als het handelen niet los kan worden gezien van de hoedanigheid van BIG-geregistreerde en er sprake is van voldoende weerslag op de individuele gezondheidszorg. ${ }^{28}$

Ook in deze verslagperiode is een aantal beroepsbeoefenaren veroordeeld wegens het in privébezit hebben van kinderpornografisch materiaal. Dit gold zowel voor een verpleegkundige (zie CTG 9 juni $2015^{29}$ met de maatregel van gedeeltelijke ontzegging van de bevoegdheid, in die zin dat de verpleegkundige geen individuele gezondheidszorg meer mag verlenen aan minderjarigen) als voor een kinderarts (zie RTG Amsterdam van 17 januari $2017^{30}$ waarin een kinderarts met onmiddellijke ingang de bevoegdheid wordt ontzegd om, in het register ingeschreven staand, het beroep van kinderarts uit te oefenen).
Interessant is een uitspraak van RTG Amsterdam van 4 juli $2017^{31}$ waarin een orthopeed die een operatie had verricht met een zaag die hij op het linkerbovenbeen van klaagster had gelegd, waarna de zaag door een technisch mankement oververhit raakte, als gevolg waarvan er een derdegraads brandwond op het been van klaagster was ontstaan, werd aangeklaagd onder meer omdat aansprakelijkheid door de verzekeraar van het ziekenhuis van de hand was gewezen en de fabrikant werd aangewezen als schuldige. De orthopeed had na het incident excuses aangeboden, maar had wel daarbij gevoegd dat hij vindt dat hij geen fout had gemaakt nu het incident was te wijten aan een technisch mankement. Het Tuchtcollege oordeelde dat nu de zaag in strijd met de gebruiksaanwijzing was gehanteerd dit moeilijk anders kon worden gekwalificeerd dan als een fout en dat verweerder dit had moeten toegeven. $\mathrm{Nu}$ klaagster echter alleen had geklaagd over het niet erkennen van aansprakelijkheid in het kader van de civiele schadeafwikkeling - het domein van de ansprakelijkheidsverzekeraar - kon de orthopeed hiervan echter geen tuchtrechtelijk verwijt worden gemaakt. Het standpunt van de orthopeed, dat hij niet betrokken was bij het civiele aansprakelijkheidstraject en de discussie daaromtrent en dat hem daarover ook geen verwijt kon worden gemaakt, acht het College overigens in zijn algemeenheid niet juist. Het feit dat een zorgverlener de civiele schadeafwikkeling doorgaans overlaat aan zijn aansprakelijkheidsverzekeraar brengt niet mee dat deze zorgverlener daarvoor geen enkele verantwoordelijkheid meer zou dragen. Het College stelt op basis van de informatie waarover het beschikte dat de schadeafwikkeling in deze zaak niet op zorgvuldige wijze had plaatsgevonden. De handelwijze van de verzekeraar was volgens het College op verschillende punten in strijd met de aanbevelingen in de GOMA. Dit in civiele aansprakelijkheidszaken niet onbekende verschijnsel, namelijk dat het patienten onevenredig veel tijd, vechtlust, geld en aandacht kost om hun schade vergoed te kunnen krijgen, acht het College verwerpelijk.

31 ECLI:NL:TGZRAMS:2017:77. 
De zorgvuldigheid die een zorgverlener op grond van artikel 47 lid 1 Wet BIG jegens een patiënt moet betrachten, omvat eveneens de manier waarop de zorgverlener na een gestelde medische fout met de patiënt omgaat. Niet valt in te zien, aldus het College, waarom dit voor de financiële afwikkeling van een incident anders zou zijn dan voor de medische afwikkeling. Dit geldt ook als de financiële gevolgen namens de zorgverlener worden afgewikkeld door een aansprakelijkheidsverzekeraar. Op het moment dat een aansprakelijkheidsverzekeraar de schade op onzorgvuldige wijze afwikkelt, ligt het op de weg van de arts zijn verzekeraar daarop aan te spreken. Omdat deze norm op het moment van het handelen van de arts wellicht nog onvoldoende bekend was, acht het College het nalaten van de arts op dit punt niet tuchtrechtelijk verwijtbaar.

RTG Zwolle besliste op 27 juli $2017^{32}$ in een zaak waarin een orthopedisch chirurg zeer veel verwijten werden gemaakt, onder meer over het vermeend niet aanwezig zijn van een informed consent, het niet aanwezig zijn van schriftelijke toestemming en het ontstaan van een dwarslaesie, over aanpassing van een operatieverslag, het nalaten van een calamiteitenmelding bij IGZ, het afhandelen van een verzoek om afgifte van een medisch dossier en het vermeend meinedig afleggen van een verklaring in het kader van een voorlopig getuigenverhoor. De arts had, na een operatie verricht op 27 november 2013, op 28 november 2013 twee zinnen aan het operatieverslag toegevoegd. Voorts had de arts op 20 januari 2014 nog een aanvulling aan het verslag toegevoegd en op 5 maart 2014 bij het verslag van een volgende operatie eveneens een opmerking toegevoegd. De arts wist op basis van login-gegevens dat zou kunnen worden vastgesteld dat dit om latere toevoegingen ging. Het College achtte dit daarmee in voldoende mate controleerbaar. Het College merkt wel op dat het beter was geweest als in de verslagen zelf was aangetekend welke aanvullingen er waren gedaan, door wie en wanneer, zodat dit ook voor anderen, in het bijzonder ook klager zelf, kenbaar was geweest en de mogelijke indruk van manipula- tie was vermeden. Dat dit echter niet was gebeurd, achtte het College tuchtrechtelijk niet verwijtbaar. Het verwijt dat de arts geen calamiteitenmelding bij IGZ had gedaan, slaagde niet, omdat die verplichting niet op de individuele arts rust maar op het ziekenhuis. Het verwijt dat pas na een aantal verzoeken een afschrift van het medisch dossier in handen werd gesteld, slaagde evenmin. De arts had het verweer gevoerd dat dit via de secretaresse orthopedie verliep en dat hij slechts toestemming voor verstrekking verleende. Het College merkt op dat de verplichting om aan de patiënt desgevraagd zo spoedig mogelijk inzage in en afschriften van (bescheiden uit) zijn dossier te verstrekken op de hulpverlener rust en dat deze er derhalve op toe dient te zien dat aan deze verplichting wordt voldaan. Verweerder had echter aan deze verplichting voldaan. Ten slotte werd de orthopeed beschuldigd van het afleggen van een meinedige verklaring onder ede. Het College stelt, in lijn met eerdere jurisprudentie, dat een arts die opzettelijk in strijd met de waarheid een verklaring aflegt omtrent de wetenschap die hij heeft als arts met betrekking tot de behandeling van zijn patiënt, handelt in strijd met het belang van een goede uitoefening van de individuele gezondheidszorg, zoals genoemd in artikel 47 lid 1 onder b Wet BIG en dat een dergelijk handelen dus tuchtrechtelijk toetsbaar is. Het College achtte echter niet aannemelijk dat de arts opzettelijk in strijd met de waarheid had verklaard.

\section{Veilig Thuis en ouderlijk gezag}

Ook in deze verslagperiode zijn weer veel klachten ingediend over het handelen c.q. rapporteren van met name artsen en psychologen aan Veilig Thuis (voorheen: AMK), de Raad voor de Kinderbescherming en/of de kinderrechter in het kader van discussies tussen ouders over het gezag van kinderen en/of de omgangsregeling en/of hun behandeling. Veelal zijn daarbij vechtscheidingen aan de orde en bestoken ouders elkaar met beschuldigingen en bezwaren. Het lijkt erop dat beroepsbeoefenaren uit de jurisprudentie van de Tuchtcolleges weinig lering trekken en zich regelmatig laten leiden door hun 
sympathie voor hun patiënt zonder zich daarbij te realiseren dat daarmee schade wordt toegebracht aan andere betrokkenen.

Hieronder volgt van de beslissingen in deze verslagperiode een selectie.

Het CTG besliste op 23 juli $2015^{33}$ in een zaak waarin een GZ-psycholoog door haar beroepsorganisatie, het Nederlands Instituut voor Psychologen, de maatregel van waarschuwing opgelegd had gekregen, waarbij was overwogen dat verweerster zich meer had kunnen inspannen om van klager toestemming te verkrijgen voor het versturen van een rapport aan het AMK en dat zij in haar rapportage terughoudender had moeten zijn. Klager klaagt vervolgens bij het Tuchtcollege over het feit dat verweerster weigerde om het rapport, zoals zij dat had uitgebracht, conform de uitspraak van het NIP aan te passen. Het RTG achtte de klacht ongegrond en stelde vast dat er geen verplichting is om een dergelijk rapport aan te passen. Het CTG liet deze beslissing in stand, maar overwoog daarbij het volgende: patiënten kunnen ernstig nadeel ondervinden in gevallen waarin komt vast te staan dat de inhoud van een door een beroepsbeoefenaar uitgebracht rapport onjuist, onvolledig of niet voldoende terughoudend is en het rapport vervolgens niet wordt gewijzigd of teruggetrokken. Het CTG kan zich voorstellen dat in die gevallen als norm heeft te gelden dat de auteur van het rapport enige vorm van actie dient te ondernemen, door het rapport aan te passen of op zijn minst door de adressant te laten weten dat de inhoud van het rapport ter discussie staat. Nadere doordenking van deze problematiek door de betrokken beroepsorganisaties ligt in de rede. De hiervoor bedoelde norm is naar het oordeel van het CTG echter nog niet zodanig uitgekristalliseerd dat de handelwijze van de GZ-psycholoog daaraan kan worden getoetst.

Het CTG heeft zich in een tweetal beslissingen gedateerd op 12 januari $2016^{34}$ uitgelaten over het handelen van een verpleegkundige op een consultatiebureau die naar aanleiding van een anonieme mel- ding, zonder met de cliënte daarover te overleggen, aan de huisarts van cliënte had medegedeeld dat zij een anonieme melding had gekregen dat klaagster mogelijk leed aan een postnatale depressie. Het RTG achtte dit verwijtbaar en in strijd met de Meldcode Huiselijk geweld en kindermishandeling, die vanaf 1 juli 2013 van kracht is geworden. In hoger beroep was het CTG het met verweerster eens dat de Meldcode Huiselijk geweld en kindermishandeling niet van toepassing was, omdat de verpleegkundige en (de eveneens aangeklaagde) arts ter zitting uitdrukkelijk hadden verklaard dat er geen vermoeden van mishandeling bestond. Het CTG achtte echter de enkele inhoud van de telefonische melding onvoldoende reden voor het gewrakte optreden van de verpleegkundige en de arts. De verpleegkundige had geen pogingen ondernomen om de melding met klaagster te bespreken en had bovendien de melding doorgegeven aan de assistente van de huisarts, omdat de huisarts afwezig was, zonder dat er sprake was van een acute situatie. De verpleegkundige was volgens het CTG in aanzienlijke mate buiten de grenzen van een redelijk bekwame beroepsuitoefening getreden en kreeg een berisping. De jeugdarts met wie zij had overlegd kwam er vanaf met een waarschuwing.

Op 22 maart 2016 deed het CTG uitspraak ${ }^{35}$ in een zaak van een GZ-psycholoog die als supervisor een verklaring had ondertekend over een ex-partner van een cliënte, waarin gesproken wordt over huiselijk geweld. Deze verklaring was gevraagd door de advocaat van de ex-partner. Verweerder wist dat deze bedoeld was om gebruikt te worden in een gerechtelijke procedure. In de verklaring werd gesproken over huiselijk geweld. Het afleggen van een dergelijke verklaring is in strijd met de beroepscode van het NIP. Daarmede heeft de GZ-psycholoog in strijd gehandeld met de binnen zijn beroepsgroep geldende richtlijnen. Het RTG voegt daaraan toe dat de problematiek rond het afgeven van verklaringen regelmatig aandacht krijgt in de vakbladen, waarbij de zorgvuldigheid die dit soort verklaringen behoeft aan de orde wordt gesteld. Ook het 
CTG tilde zwaar aan het aan de GZ-psycholoog te maken verwijt en handhaaft de hem opgelegde maatregel van berisping.

RTG Amsterdam besliste op 30 augustus $2016^{36}$ over een klacht in een zaak waarin de aangeklaagde arts/vertrouwensarts op basis van een vermoeden van kindermishandeling een onderzoeksrapport had opgesteld. De vraagstelling van het onderzoeksrapport werd onvoldoende neutraal geacht. Verweerster was bij het formuleren van die vraagstelling mede betrokken. Verder had verweerster een kinderarts die gedurende ruim vijf jaar de behandelaar was geweest van de kinderen niet geraadpleegd alvorens het rapport op te stellen. Deze keuze had zij in het rapport niet toegelicht. Verder had zij geciteerd uit brieven van behandelaren zonder daarmee in voldoende mate precies te zijn. Zo had zij overgenomen dat klaagster een borderlinepersoonlijkheidsstoornis had, terwijl in de desbetreffende rapportage stond dat klaagster trekken van een borderlinepersoonlijkheidsstoornis had. Ten slotte had zij haar rapport niet in concept aan klaagster doen toekomen met als argument dat het rapport niet kon worden beschouwd als een zelfstandig rapport, maar geschreven zou zijn in opdracht van en in samenspraak met de Raad voor de Kinderbescherming. Dit rapport met inbegrip van de bijlagen, namelijk het rapport van verweerster, was wel in concept voorgelegd aan klaagster. Het Tuchtcollege vond dit echter niet voldoende, gezien de verstrekkendheid van de rapportage van verweerster en stelde dat verweerster vanuit een zorgvuldige onderzoeksopzet in het bijzonder uit oogpunt van hoor en wederhoor klaagster in de gelegenheid had moeten stellen om kennis te nemen van het rapport, zodat zij daarop had kunnen reageren voordat het werd overhandigd aan de Raad voor de Kinderbescherming. Het nalaten daarvan was onzorgvuldig. Verweerster kreeg de maatregel van waarschuwing opgelegd.

Het Tuchtcollege Zwolle oordeelde op 8 april $2016^{37}$ dat een GZ-psycholoog bij de door haar

36 Op tuchtrecht.nl op datum 25 oktober 2016, in de GJ op 30 augustus 2016: ECLI:NL:TGZRAMS:2016:59.

37 ECLI:NL:TGZRZWO:2016:38. gedane AMK-melding niet had voldaan aan haar plicht om dat signaal te onderbouwen. De GZ-psycholoog had klager nimmer gezien en de mededelingen van de ex-partner van klager groter gemaakt, waarbij zij bovendien had vermeld dat klager sadistische trekken zou hebben, weloverwogen agressief gedrag zou vertonen, een cluster B-persoonlijkheid (antisociaal en narcistisch) zou hebben, geen empathie zou tonen, geen spijt zou hebben, zich verongelijkt en gekrenkt zou voelen en zou externaliseren. De klachten daarover zijn derhalve gegrond. Het Tuchtcollege meent ten aanzien van de AMK-melding dat een GZ-psycholoog geacht wordt zich te houden aan de KNMG-meldcode. Deze schrijft voor dat de behandelaar zo mogelijk voorafgaand aan de melding een gesprek moet voeren met beide ouders. Verweerster heeft dit niet gedaan. Haar cliënte had toestemming daarvoor geweigerd, omdat zij bang was voor escalatie. Verweerster heeft conform stap 2 van het stappenplan zich breed georiënteerd, onder andere bij het AMK en de SHG. De SHG had haar laten weten de situatie zeer ernstig en zorgelijk te vinden en het ook nader geconcretiseerd. Voorts had haar cliënte zelf een melding van huiselijk geweld gedaan bij de politie. Tegen die achtergrond en in het bijzonder gelet op de uitspraken die de SHG tegen verweerster had gedaan omtrent de mogelijke (on)veiligheid van de kinderen heeft verweerster zonder voorafgaand contact met klager de AMK-melding mogen doen. Dit klachtonderdeel werd derhalve afgewezen. Verweerster had verder ter zitting het nodige zelfinzicht laten zien. Het College volstaat mede om die reden met de maatregel van waarschuwing.

RTG Den Haag oordeelde op 14 maart $2017^{38}$ over een verklaring die een gezondheidszorgpsycholoog, bij wie de echtgenoot van klaagster onder behandeling was geweest in verband met een posttraumatische stressstoornis, had afgegeven aan de advocaat van de echtgenoot. In de verklaring stelde de gezondheidszorgpsycholoog dat de echtgenoot in staat was om voor zijn kinderen te zorgen, een liefdevolle, zorgzame vader was en dat het van belang

ECLI:NL:TGZRSGR:2017:42. 
was dat er goede afspraken kwamen over de verdeling van de zorgtaken en het verblijf van de kinderen. De gezondheidszorgpsycholoog was op de hoogte van de breuk tussen de man en zijn ex-echtgenote en verstrekte de verklaring aan de advocaat van de man met het oog op de expliciet door hem gestelde vraag of het verantwoord was als de kinderen in het kader van een omgangsregeling bij hem verblijven. De gezondheidszorgpsycholoog had zich niet uitgelaten over klaagster en haar mogelijkheden om voor de kinderen te zorgen, maar enkel over haar patiënt. Desalniettemin berispt het RTG de gezondheidszorgpsycholoog met een beroep op de KNMG-richtlijn Omgaan met medische gegevens van september 2016 en de Beroepscode voor psychologen van het NIP uit 2015. Naar het oordeel van het College bevat de hierboven weergegeven verklaring waardeoordelen over de man die niet een behandeldoel dienen. Het College is het niet eens met verweerster dat haar brief slechts feitelijke en objectieve informatie bevat. Een wel heel streng oordeel!

Een soortgelijke zaak, maar dan inhoudelijk wat betreft de verklaring ernstiger, betrof het oordeel van RTG Den Haag van 6 december $2016^{39}$ waarin een GZ-psycholoog, ditmaal als behandelaar van de moeder, een verklaring aan haar advocaat had afgegeven over het feit dat zij aangifte had gedaan van strafbare feiten begaan door haar ex-echtgenoot. De GZ-psycholoog had in de verklaring opgenomen dat hij geen reden had om te twijfelen aan het feit dat de moeder deze zaken van haar kinderen had gehoord. Als deze informatie juist was, aldus de GZpsycholoog in haar verklaring, is hier sprake van een mate en soort van geweld dat buitengewoon schadelijk is voor kinderen. Het NIP had de GZ-psycholoog al berispt voor deze verklaring. Na deze beslissing van het NIP had de GZ-psycholoog de moeder nog nader geadviseerd over problemen met de kinderen. Het Tuchtcollege achtte het niet tuchtrechtelijk verwijtbaar dat de GZ-psycholoog zijn cliënte opvoedingsadviezen gaf, ook nadat er een klacht tegen hem was ingediend, nu niet is gebleken dat hij daarmee buiten de begrenzing van zijn professie is getreden. De klacht over de verklaring achtte het Tuchtcollege gegrond. Het Tuchtcollege legt de maatregel van berisping op, omdat het gaat om een basale fout met mogelijk zeer schadelijke gevolgen, waaromtrent een duidelijke norm bekend is en verweerder bovendien lang had volgehouden dat hij toch juist had gehandeld.

Het CTG oordeelde op 12 april 2016 over een soortgelijke zaak. ${ }^{40}$ In dit geval betrof het een psychotherapeut die op verzoek van de ex-partner van klaagster een second opinion had uitgebracht over een rapportage die door een ggz-instelling was opgesteld over de dochter van klaagster in het kader van een echtscheidingsprocedure. Er was sprake van een vechtscheiding. Het CTG achtte het uitbrengen van een second opinion in een dergelijke situatie op zich geoorloofd, maar oordeelt dat vanwege het precaire karakter van de situatie terughoudendheid geboden is, zeker als het verzoek afkomstig is van slechts één van de bij de vechtscheiding betrokken partijen. In dit geval had die terughoudendheid eruit kunnen bestaan dat de psychotherapeut zich had beperkt tot het plaatsen van kanttekeningen bij het rapport van de instelling. Dit is echter niet wat de psychotherapeut had gedaan. Zonder dat zij klaagster en de dochter had gezien, deed zij verregaande uitspraken over de persoonlijkheid en mogelijke psychopathologie van klaagster en haar dochter, terwijl zij wist dat de second opinion in een gerechtelijke procedure zou worden gebruikt. De rapportage was vooraf noch aan klaagster noch aan haar dochter voorgelegd. Het CTG achtte de gebruikte methode van onderzoek een volstrekt onvoldoende basis voor de door verweerster gestelde diagnoses, het ging slechts om een papieren onderzoek op basis van de documenten die waren afgeleverd door de ex-partner van klaagster. De door het RTG opgelegde berisping wordt gehandhaafd.

Tot slot is nog opvallend de beslissing van het CTG van 10 januari $2017^{41}$ waarin een waarschuwing die een GZ-psycholoog van RTG Amsterdam had

40 ECLI:NL:TGZCTG:2016:164.

41 ECLI:NL:TGZCTG:2017:11. 
gekregen, werd vernietigd en alsnog alle klachten werden afgewezen. De GZ-psycholoog had na een zeer zorgvuldig en herhaald traject en na overleg met collegae en Veilig Thuis uiteindelijk een zorgmelding gedaan toen het niet lukte om een hulpverleningstraject op gang te brengen en een veiligheidsplan tot stand te brengen en een zogenoemd Signs of Safety-traject op te starten. De zorgmelding gebeurde zonder toestemming van klaagster, hetgeen naar het oordeel van het RTG met zich had moeten brengen dat verweerster naar een mogelijkheid had moeten zoeken die minder inbreuk had gemaakt op de privacy dan een zorgmelding. Het CTG beoordeelde de zaak anders. Aan de hand van de meldcode van de instelling waar de GZ-psycholoog werkzaam was volgt het College de in de code opgenomen stappen. Mede aan de hand van het buitengewoon zorgvuldig bijgehouden dossier door de GZ-psycholoog komt het CTG tot afwijzing van alle ingediende klachten. Nu de GZ-psycholoog meerdere malen had getracht het hulpverleningstraject opgestart te krijgen, maar dit niet lukte, stelt het CTG dat de zorgmelding wel zorgvuldig is verricht, ook omdat het niet mogelijk was om een Signs of Safety-traject op te starten, onder meer door het ontbreken van toestemming van klaagster. Klaagster was van tevoren telefonisch op de hoogte gesteld van het voornemen om een zorgmelding bij Veilig Thuis te doen, ook al gaf zij daarvoor geen toestemming. Dit lijkt een belangrijke beslissing in de worsteling van hulpverleners wanneer nu wel en wanneer nu geen zorgmelding kan/moet worden gedaan.

\section{Tuchtmaatregelen: doorhalingen en (voorwaardelijke) schorsingen}

In deze verslagperiode zijn weer talloze doorhalingen en schorsingen door Tuchtcolleges uitgesproken. Waren dit vroeger maatregelen die zelden werden opgelegd, tegenwoordig lijken zij vaker voor te komen. Het gaat dan in het algemeen óf om ernstig disfunctionerende artsen, vaak in combinatie met alternatieve behandelwijzen, óf om artsen die een seksuele relatie met hun patiënten zijn aangegaan, óf artsen die fraude plegen. Hieronder volgt een selectie.

RTG Den Haag haalde op 27 oktober $2015^{42}$ een arts door die experimentele behandelingen op een kankerpatiënt toepaste, die in diverse opzichten onder de maat werden geacht. Patiënten werden onjuist en onvolledig voorgelicht, er was sprake van gebrekkige dossiervoering en er was geen borging van kwaliteit en veiligheid van de experimentele behandeling. De arts ging in hoger beroep met als kernargument dat hij niet eerder tuchtrechtelijk was aangeklaagd en niet langer als arts werkzaam wilde zijn, dat wil zeggen geen directe patiëntenzorg meer wilde verlenen, maar dat zijn BIG-registratie voor hem van groot belang was omdat hij zich naar zijn (internationale) professionele contacten wilde kunnen blijven presenteren als arts. Het CTG handhaaft op 15 november $2016^{43}$ de doorhaling, omdat het College er geen vertrouwen in heeft dat de arts zich in de toekomst wel aan toepasselijke wetgeving, richtlijnen en protocollen zal houden.

Het Tuchtcollege Den Haag haalde op 3 november $2015^{44}$ een verpleegkundige door die vele malen bloedsuikerwaarden van één cliënte niet had gecontroleerd en onjuist had genoteerd, alsmede als financieel beheerder van meerdere cliënten gedurende meerdere jaren onrechtmatig uitgaven had geboekt en bedragen had verduisterd. Dit betrof een bedrag van bijna $€ 80.000$. De verpleegkundige erkende de klachten grotendeels, hoewel hij de hoogte van het fraudebedrag betwistte. Het College oordeelde dat hij had gehandeld in strijd met de Nationale Beroepscode van Verplegenden en Verzorgenden en in strijd met artikel 47 lid 1 onder a en b Wet BIG. Hoewel de verpleegkundige had verklaard niet meer als verpleegkundige werkzaam te willen zijn, achtte het College toch een kans op herhaling reëel. De verpleegkundige werd doorgehaald met onmiddellijke ingang, waarbij tevens als voorlopige voorziening een schorsing van de inschrijving werd opgelegd.

\footnotetext{
42 ECLI:NL:TGZRSGR:2015:136

43 ECLI:NL:TGZCTG:2016:336.

44 ECLI:NL:TGZRSGR:2015:138.
} 
In zijn uitspraak van 19 januari $2016^{45}$ herhaalt het CTG nog eens onder verwijzing naar zijn beslissing van 10 april $2014^{46}$ dat het aangaan van een seksuele relatie met een patiënt in beginsel ten minste een schorsing van de inschrijving van de aangeklaagde in het BIG-register met zich brengt, afhankelijk van de zich voordoende omstandigheden, zoals het gevaar van recidive, mede in het licht van de aan de tuchtrechter gebleken mate waarin de aangeklaagde zich bewust is van het verkeerde van zijn of haar gedragingen en zijn of haar bereidheid en mogelijkheden zo nodig een behandeling te ondergaan om recidive te voorkomen. In dit concrete geval wordt de verpleegkundige een schorsing van zes maanden opgelegd.

RTG Eindhoven schorste een verpleegkundige voorwaardelijk voor de duur van drie maanden op 14 maart 2016. ${ }^{47}$ De verpleegkundige had een affectieve en vervolgens seksuele relatie met een patiënt die in behandeling was van haar werkgever, maar zij wist aanvankelijk niet dat er een behandelrelatie tussen de patiënt en haar werkgever bestond. Op enig moment kwam zij daarvan wel op de hoogte. Zij kon er echter niet toe komen om haar relatie bij de vertrouwenspersoon van haar werkgever te melden. Het Tuchtcollege legt niet zonder meer de maatregel van onvoorwaardelijke schorsing op, omdat de verpleegkundige niet rechtstreeks bij de behandeling van patiënte betrokken was en omdat uit de Beroepscode voor Verpleegkundigen niet expliciet duidelijk is dat ook privérelaties met patiënten die niet persoonlijk worden behandeld verboden zijn.

Een zaak van andere orde is de veroordeling van een plastisch chirurg in eerste instantie tot de schorsing van één jaar, in hoger beroep teruggebracht tot een voorwaardelijke schorsing van vier maanden. ${ }^{48}$ De plastisch chirurg was werkzaam in een privékliniek met een beperkte bezetting van medisch personeel, waardoor de organisatie van een adequate nazorg in geval van complicaties kwetsbaar is en afhankelijk is van de aanwezigheid van de plastisch chirurg en de bereidheid van het overige medische personeel om in geval van een lastminuteoproep naar de kliniek te komen. Daarbij ontbrak het structureel aan een adequate regeling op basis waarvan bij eventuele complicaties de continuiteit van de nazorg voor de patient door een arts van een nabijgelegen regulier ziekenhuis verzekerd was. Ook was de organisatie te zeer ingesteld op operatieve nazorg op basis van lokale verdoving, waarbij de mogelijkheid om na een complicatie onder algehele verdoving te worden geopereerd niet standaard als alternatief aan de patient kon worden aangeboden of met patiënt werd besproken. Het CTG trok overigens niet in twijfel dat de plastisch chirurg vakbekwaam was en dat zij het beste met haar patiënten voorhad. Verder had het CTG kunnen vaststellen dat de plastisch chirurg naar aanleiding van het onderzoek van de Inspectie concrete stappen had ondernomen om de organisatie op diverse punten structureel te verbeteren.

Op 4 oktober 2016 schorste het CTG $^{49}$ een kaakchirurg/arts voorwaardelijk voor de duur van drie maanden met een proeftijd van twee jaar in een zaak waarin het RTG hem een onvoorwaardelijke schorsing van de inschrijving in het BIG-register voor de duur van drie maanden had opgelegd. Een aantal door het RTG gegrond verklaarde klachtonderdelen werden ongegrond verklaard. Anders dan in eerste aanleg was de arts nu wel ter zitting van het CTG verschenen om een aantal zaken uit te leggen. Voorts had de arts in hoger beroep zijn onverschillige houding in eerste aanleg laten varen en zich alsnog toetsbaar opgesteld en waren de gewraakte gebeurtenissen ruim tien jaar geleden, zonder dat de arts ooit eerder in aanraking was geweest met het tuchtrecht.

Opvallend is een beslissing in eerste instantie van RTG Zwolle van 25 november 2016, ${ }^{50}$ naderhand bevestigd door het CTG op 6 juli 2017,,51 waar het ging om een apotheker die verdacht werd van het stelselmatig plegen van fraude en het ten onrechte in rekening brengen van kosten voor gezondheidszorg. Klager was in dit geval een zorgverzekeraar in

49 ECLI:NL:TGZCTG:2016:303 en 304.

50 ECLI:NL:TGZRZWO:2016:130.

51 ECLI:NL:TGZCTG:2017:201. 
de zin van de Zorgverzekeringswet. Een zorgverzekeraar is op grond van artikel 65 lid 1 onder c Wet BIG bevoegd een klacht in te dienen als hij met de betreffende beroepsbeoefenaar een overeenkomst heeft gesloten. Zorgverzekeraars maken van deze bevoegdheid echter zelden gebruik. Het Tuchtcollege in eerste aanleg had de zorgverzekeraar terecht - ontvankelijk geacht en oordeelde dat het handelen van verweerder zowel onder de tweede tuchtnorm als onder de eerste tuchtnorm werd bestreken. Het CTG verenigde zich met dit oordeel. Ten aanzien van het verweten frauderen, althans ten onrechte kosten voor de gezondheidszorg in rekening brengen, overwoog het CTG dat de apotheken waarvoor verweerder verantwoordelijk was c.q. waarin hij bestuurder was zodanig hoge bedragen hadden gedeclareerd dat dit tot vraagtekens had moeten leiden. Zo schommelde de omzet van een van de apotheken van verweerder tussen de $€ 118.000$ en $€ 723.000$ per jaar. Ook bij een andere zorgverzekeraar had de apotheker veel te hoge bedragen gedeclareerd. De apotheker had gehandeld in strijd met de Beroepscode van Apothekers en het Handvest van de apotheker en daarbij op geen enkele wijze blijk gegeven rekening te houden met het belang van zijn patiënten en met het feit dat de maatschappij vertrouwen in het ambt van een apotheker moet kunnen hebben. Voorts had hij geen inzicht getoond in de laakbaarheid van zijn handelen door alles te ontkennen en veelvuldig tegenstrijdig en niet sluitend over zijn handelen te verklaren. Het CTG nam het oordeel van het RTG over, dat de apotheker zich jegens klaagster schuldig had gemaakt aan declaratiefraude en deze beschuldiging niet had kunnen ontzenuwen. Dit handelen acht het College zodanig in strijd met een goede uitoefening van de individuele gezondheidszorg dat een onmiddellijke doorhaling van de inschrijving van de apotheker in het BIG-register terecht was.

Alleen al in 2017 haalde RTG Zwolle tot 1 september van dit jaar vijfmaal een beroepsbeoefenaar door. Op 20 januari klaagde IGZ een sociaalpsychiatrisch verpleegkundige aan. Hij behandelde een patiente van 14 jaar die bij haar moeder, tevens nevenpatiënte, woonde. Tussen verweerder en nevenpati- ente ontstond een intieme relatie inclusief seksueel contact. In de zomer van 2014 woonde de verpleegkundige meerdere weken bij haar in huis. Het Tuchtcollege haalt verweerder door met een uitvoerige motivatie waarom niet volstaan kan worden met een schorsing. Dit is met name gelegen in het feit dat verweerder zich niet onder therapeutische behandeling heeft gesteld en het College niet kan uitsluiten dat verweerder in de toekomst weer als verpleegkundige aan het werk gaat en dat verweerder geen inzicht heeft in het hoe en waarom hij tot grensoverschrijdend gedrag is gekomen en hem het besef ontbreekt dat - juist daarom - recidive niet uit te sluiten is. ${ }^{52}$

Op 31 maart 2017 haalde het Tuchtcollege Zwolle een huisarts door. De huisarts had een patiënte met psychische problemen seksueel gekleurde e-mailberichten gezonden en op een avond bij haar thuis fysiek contact met haar gehad door haar rug te masseren, haar borsten, buik en vagina te strelen en haar te zoenen. Het College achtte onvoldoende aanwijzingen aanwezig dat er geen risico op recidive bestaat. Wel had verweerder zich onder behandeling van een psycholoog geplaatst, maar het was voor het College niet duidelijk waar deze therapie precies op was gericht en wat de vorderingen waren. De huisarts wordt doorgehaald. ${ }^{53}$

Op 18 juli 2017 haalde het Tuchtcollege een orthodontist door die ervan beschuldigd werd dat hij met twaalf, merendeels jonge, patiënten seksueel grensoverschrijdend gedrag zou hebben vertoond door hen te strelen, op de billen te slaan, over hun wang te wrijven c.q. te strelen en hun borsten aan te raken. De orthodontist ontkende deze gebeurtenissen. Het Tuchtcollege achtte een zodanig gebrek aan respect voor patiënten onderdeel van verweerders handelen dat alleen een doorhaling geëigend was. Daarbij speelde ook een rol dat een gedeeltelijke doorhaling, bijvoorbeeld door te verbieden vrouwelijke patiënten te behandelen, nauwelijks uitvoerbaar werd geacht respectievelijk nauwelijks controleerbaar zou zijn. ${ }^{54}$

\footnotetext{
52 ECLI:NL:TGZRZWO:2017:16.

53 ECLI:NL:TGZRZWO:2017:67.

54 ECLI:NL:TGZRZWO:2017:134.
} 
Op 18 augustus $2017^{55}$ ten slotte haalde RTG Zwolle een psychiater/psychotherapeut in beide registraties door omdat deze door zijn grensoverschrijdende gedragingen als arts heeft gehandeld in strijd met de KNMG-richtlijn 'Seksueel contact tussen arts en patiënt: het mag niet, het mag nooit' en met gedragsregels II.1 en II12 van de KNMGgedragsregels voor artsen, en als psychotherapeut in strijd met artikel II.1.1.1, II.5.1.1 en II.5.1.2 van de Beroepscode voor psychotherapeuten. In de behandeling van klaagster is hij daarmee ernstig tekortgeschoten. Verweerder heeft aldus gehandeld in strijd met de zorg die hij ingevolge artikel 47 lid 1, aanhef en onder a Wet BIG had behoren te betrachten. Het RTG meent niet te kunnen volstaan met een schorsing, om een aantal redenen. Verweerder erkent weliswaar dat het hem verweten kan worden dat hij een seksuele relatie is aangegaan met klaagster, maar hij stelt zich in de stukken en ook ter zitting op als slachtoffer van de avances van klaagster. Ook onjuist en grensoverschrijdend acht het RTG dat verweerder klaagster zijn privételefoonnummer heeft gegeven en op zijn privételefoon via WhatsApp vertrouwelijke informatie met klaagster heeft uitgewisseld over de toestand van klaagster en over haar medicatie. Dat verweerder zich onder behandeling heeft gesteld van een psychiater acht het College juist. Het College is echter, zoals uit de hierboven staande overwegingen blijkt, onvoldoende overtuigd dat verweerder thans voldoende inzicht heeft in het grensoverschrijdende van zijn handelen en zijn eigen rol daarin en daarom is het College er onvoldoende van overtuigd dat hij in die behandeling voldoende kan veranderen om herhaling te voorkomen. Het College ziet daarom, mede gelet op de ernst van het aan verweerder te maken verwijt, geen andere mogelijkheid dan verweerder de maatregel van doorhaling van de inschrijving in BIGregister op te leggen en bij wijze van voorlopige voorziening de schorsing van de inschrijving van verweerder in het BIG-register.

\section{Dossiervoering}

In deze verslagperiode is regelmatig geklaagd over dossiergerelateerde zaken. De klacht zag dan in de regel niet enkel of primair op de wijze van dossiervoering, het betrof veelal slechts een (klacht)onderdeel.

Relatief vaak werd geklaagd over onvolledigheid en onjuistheid van het medisch dossier. Zo werd een tandarts onder meer gebrekkige dossiervoering verweten. Het CTG verwijst naar de geldende regels op het gebied van dossiervoering, met name artikel 7:454 lid 1 BW. Opgemerkt wordt dat zorgvuldig dossierbeheer van belang is voor goede hulpverlening; het waarborgt de continuiteit van het gevolgde, in casu, tandheelkundige beleid. Hoewel de dossiervoering beknopt mag zijn, geldt als minimumnorm dat duidelijk moet zijn welke behandeling is uitgevoerd en op basis van welke gegevens. In casu was zorgvuldig dossierbeheer temeer van belang, daar de tandarts werkzaam was in een grote tandartsenpraktijk waar meerdere tandartsen in dienst waren en waar het niet ongewoon was dat een patiënt 'tussendoor' ook behandeld werd door een andere tandarts. Het CTG concludeert, in navolging van het RTG, dat het patiëntendossier te summier is en niet het voornoemde minimum aan informatie bevat. Ten aanzien van het verweer van de tandarts dat de eigenaren van de praktijk regelmatig digitale gegevens uit patiëntendossiers zouden hebben verwijderd om opslagcapaciteit vrij te maken, stelt het CTG dat er geen aanwijzingen zijn dat dit in het patiëntendossier van klager ook is gebeurd. Bovendien ontslaat dat de tandarts niet noodzakelijkerwijs van diens eigen verantwoordelijkheid daarin. ${ }^{56}$

56 CTG 25 augustus 2016, ECLI:NL:TGZCTG:2016:273, G) 2017/22. Zie ook: RTG Amsterdam 23 mei 2017, ECLI:NL:TGZRAMS:2017:61 (klacht van de IGZ tegen een arts/gezondheidszorgpsycholoog. Het RTG overwoog dat een goede verslaglegging van wezenlijk belang is in het kader van een goede en adequate beoordeling van het professioneel handelen van de zorgverlener en in het kader van continuiteit van zorg). 
Vergelijkbaar werd geoordeeld ter zake van een klacht over een tandarts die eveneens onvoldoende dossiervoering werd verweten. De tandarts in kwestie erkende zijn tekortkomingen op dit punt. Ook RTG Den Haag verwees naar artikel 7:454 BW, waarin de dossierplicht is verankerd. In het dossier dient aantekening te worden gehouden van de gegevens omtrent de gezondheid van de patiënt en de uitgevoerde verrichtingen, een en ander voor zover dit voor een goede hulpverlening aan de patiënt noodzakelijk is. Goede, toegankelijke en begrijpelijke verslaglegging is volgens de tuchtrechter van groot belang niet alleen voor de kwaliteit en continuiteit van de zorgverlening en begeleiding, maar ook vanwege de verantwoording en toetsbaarheid van het handelen van de hulpverlener. In casu voldoet het dossier daar niet aan, het is te summier. Het dossier bevat geen vermelding van de inhoud van gevoerde gesprekken en de afspraken over het te voeren beleid, hetgeen aangewezen was gelet op de toestand van klagers gebit. ${ }^{57}$

RTG Zwolle komt tot dezelfde overwegingen bij de beoordeling van een klacht tegen een plastisch chirurg die eveneens summiere en onvolledige verslaglegging werd verweten. Vervolgens wordt geoordeeld dat de plastisch chirurg zijn dossierplicht heeft verzaakt. Hoewel klaagster een behandelingsovereenkomst heeft getekend, is nergens uit af te leiden in hoeverre zij is voorgelicht over de behandelmogelijkheden en de daarbij behorende risico's, laat staan dat zij de informatie heeft begrepen. Ook is er geen verslaglegging aanwezig van hetgeen de plastisch chirurg aan lichamelijk onderzoek heeft gedaan. Ten aanzien van de eerste operatie die bij klaagster is uitgevoerd heeft de plastisch chirurg genoteerd dat deze is uitgevoerd conform behandelprotocol BP01, waarbij geen complicaties zijn opgetreden. Het RTG is van mening dat de enkele verwijzing naar dit behandelprotocol niet kan worden gezien als een operatieverslag. Het operatieverslag voldoet derhalve niet aan de daaraan te stellen eisen. Ditzelfde geldt voor het verslag van de tweede operatie van klaagster. Daarin wordt op dezelfde

manier verwezen naar genoemd protocol, dit terwijl het twee wezenlijk verschillende operaties betrof. Het RTG concludeert dat de ontbrekende, althans zeer magere, dossiervorming tuchtrechtelijk verwijtbaar is. ${ }^{58}$

In een andere zaak verweet de IGZ een waarnemend huisarts, onder andere, onjuiste en onvolledige dossiervoering. RTG Amsterdam oordeelde dat, zoals de huisarts stelde, inderdaad niet álles hoeft te worden vermeld, maar wel al hetgeen dat relevant is. Geconcludeerd wordt dat, gezien de geuite klachten, de gestelde diagnose en hetgeen de huisarts heeft gesteld omtrent de omvang van het uitvragen, niet alle relevante gegevens in het medisch dossier zijn vermeld. ${ }^{59}$

Een andere klacht zag niet alleen op de onzorgvuldigheid van de dossiervoering, maar ook op de subjectieve wijze waarop een en ander was opgetekend. De betreffende sociaalpsychiatrisch verpleegkundige werd verweten dat zij zich heeft bediend van onzorgvuldige en uitermate subjectieve dossiervoering. RTG Amsterdam overweegt dat subjectiviteit inherent is aan rapportage van een behandelproces. Bovendien is niet vast komen te staan dat de rapportage een onjuist beeld geeft van de behandeling of uiterst onzorgvuldig is, aldus het RTG. ${ }^{60}$

Adequate dossiervoering bij het afwijken van een richtlijn acht de tuchtrechter van groot belang. Een longarts werd verweten dat hij voor de chemotherapie, in afwijking van de landelijke richtlijn, had gekozen voor de combinatie Carboplatin-Pemetrexed zonder dit met de patiënt en klaagster (de partner van de patiënt) te bespreken en in het medisch dossier vast te leggen. Het CTG overwoog dat de longarts aan het begin van de behandeling een afweging heeft gemaakt van de voor- en nadelen van een combinatiechemotherapie met Carboplatin of Cisplatin. Zijn persoonlijke voorkeur voor de combinatie Carboplatin-Pemetrexed boven de in de lande-

58

59

60
RTG Zwolle 11 november TGZRZWO:2016:121.

RTG Amsterdam 27 oktober 2015, ECLI:NL: TGZRAMS:2015:93, GJ 2016/5.

RTG Amsterdam 23 augustus 2016, ECLI:NL: TGZRAMS:2016:52, GJ 2016/150. 
lijke richtlijn aanbevolen combinatie CisplatinPemetrexed, werd bepaald door het feit dat Carboplatin minder bijwerkingen voor de patiënt zou geven dan Cisplatin en er qua werking weinig verschil bestond. Deze afweging en de daaruit voortvloeiende keuze acht het CTG, mede gelet op de overwegingen in de richtlijn, verdedigbaar. Het wordt de longarts echter, mede omdat de richtlijn een andere combinatie voorschreef, wel aangerekend dat hij heeft nagelaten de patiënt (en klaagster) daarover te informeren. Het eindoordeel op dit punt luidt dan ook dat de longarts tuchtrechtelijk verwijtbaar heeft gehandeld door zijn afweging en keuze niet met de patiënt en klaagster te bespreken en ook niet in het medisch dossier te noteren. ${ }^{61}$

Opmerkelijk was een zaak waarin de Inspectie klaagde over een alternatief werkzaam basisarts, die gratis - door hemzelf ontwikkelde - homeopathische medicatie ter beschikking had gesteld aan een arts in Kenia voor de behandeling van hiv-patiënten en over de resultaten van de behandeling had gepubliceerd. Hem werd verweten dat hij in strijd had gehandeld met de Verklaring van Helsinki door bij dit onderzoek de fundamentele rechten van kwetsbare patiënten onvoldoende in acht te nemen. RTG Amsterdam was aanvankelijk van oordeel dat van medisch-wetenschappelijk onderzoek geen sprake was. ${ }^{62}$ Het CTG denkt hier echter anders over en meent vervolgens dat de arts het verdrag op wezenlijke gronden heeft geschonden. Daarbij tekent het Centraal Tuchtcollege nog aan dat ook bij gerede twijfel omtrent het karakter van het onderzoek toetsing door de daarvoor aangewezen commissie geboden is. De Inspectie verweet de arts verder dat hij ten aanzien van zijn Nederlandse praktijkvoering onvoldoende invulling had gegeven aan de verzwaarde informatie- en dossierplicht die op grond van de KNMG-gedragsregel 'De arts en niet-reguliere behandelwijzen' op hem als alternatief arts rusten. In de KNMG-gedragsregel staat dat de arts die een niet-reguliere behandelwijze overweegt, aan de pati-

61 CTG 9 februari 2016, ECLI:NL:TGZCTG:2016:70, GJ 2016/47.

62 RTG Amsterdam 20 december 2016, ECLI:NL: TGZRAMS:2016:77, GJ 2017/27 m.nt. J.C.J. Dute. ent het verschil tussen reguliere en niet-reguliere behandelwijzen duidelijk moet maken. Daarnaast moet een patiënt die een geïndiceerde behandelwijze afwijst en een niet-reguliere behandelwijze overweegt, door de arts worden gewezen op de mogelijke gevaren van het uit- of afstellen van reguliere behandelwijzen. Het blijft te allen tijde de verantwoordelijkheid van de arts om de patiënt te wijzen op het belang van reguliere behandelwijzen en daarnaar steeds te verwijzen, aldus de KNMGgedragsregel. De arts dient daarvan op zorgvuldige wijze aantekening te houden. De tuchtrechter in eerste aanleg achtte het echter van belang dat de aangeklaagde arts zich naar buiten toe presenteert als 'arts voor homeopathie'. De naamgeving van zijn praktijk laat daarover geen misverstand bestaan. De arts heeft, onweersproken, verklaard dat hij één uur uitrekt voor het eerste consult, dat op internet de informatie over zijn homeopathische praktijk te vinden is en dat zijn patiëntenpopulatie bestaat uit personen die bewust kiezen voor homeopathie. Het feit dat in het dossier geen aparte aantekening is gemaakt zoals omschreven in de KNMG-gedragsregel, kan hier de toets der kritiek doorstaan. Het kan de arts tuchtrechtelijk niet worden verweten dat in de door de Inspectie onderzochte (enkele) dossiers, niet is opgenomen dat er sprake is van 'informed consent' over de niet-reguliere behandeling. Uit het ontbreken van aantekeningen in het dossier ter zake volgt niet dat niet aan het informedconsentvereiste is voldaan. Informed consent is bovendien een 'reguliere' wettelijke plicht in de zin van artikel 7:450 lid 1 BW. De wet schrijft, in artikel 7:451 BW, enkel ten aanzien van ingrijpende verrichtingen voor dat die toestemming, op verzoek van de patient, schriftelijk moet worden vastgelegd. De slotsom is dat niet gesteld of gebleken is dat de patiënten van de arts (in die onderzochte dossiers) onvoldoende zijn voorgelicht enkel omdat de aantekening daarover ontbreekt en/of dat arts zijn patiënten van de reguliere (geïndiceerde) behandelwijzen heeft afgehouden. Het CTG verenigt zich met de overwegingen van de lagere tuchtrechter en voegt daar aan toe dat 'zaken die vanzelf spreken geen documenta- 
tie behoeven'.63 Daarmee blijft duister hoever de documentatieplicht bij de niet-reguliere behandeling dan wel reikt.

In een andere opmerkelijke zaak had een arts (voormalig internist) kankerpatiënten die geen uitzicht op genezing hebben behandeld met experimentele geneesmiddelen. Een van de klachten van de Inspectie zag op onvoldoende dossiervoering. RTG Den Haag stelde voorop dat een zorgvuldige dossiervorming, in het kader van de kwaliteit en continuiteit van de zorgverlening en het inzichtelijk maken daarvan, voor elke vorm van patiëntenzorg van belang is. De wettelijke plicht ex artikel 7:454 BW dat een hulpverlener, voor zover noodzakelijk voor een goede hulpverlening, een dossier inricht en daarin aantekeningen maakt van de gegevens omtrent de gezondheid van de patiënt, de uitgevoerde verrichtingen en andere stukken met zodanige gegevens, is er immers met een reden. ${ }^{64}$ Vervolgens overweegt het RTG dat in casu een extra zware dossierplicht geldt, daar sprake is van een behandeling met experimentele medicatie die niet eerder is toegepast op mensen en die niet wetenschappelijk is onderzocht. Derhalve mag van de arts worden verwacht dat hij in detail beschrijft wat het effect van de behandeling is, of er al dan niet bijwerkingen of complicaties optreden en wat de mogelijke oorzaak daarvan is. De onderliggende onderzoeksuitslagen horen eveneens in het dossier te worden gevoegd. Het beleid wordt daarmee, ook voor andere (opvolgende) behandelaren, inzichtelijk én de arts kan verantwoording afleggen over het door hem gevoerde beleid. De IGZ heeft van de arts, met toestemming van de betreffende patiënten, de dossiers van drie patiënten ontvangen. Daarin trof het RTG over de behandeling slechts twee A4'tjes aan met de data waarop de patiënt de kliniek heeft bezocht en, indien van toepassing, de medicatie die toen is toegediend. Noodzakelijke informatie, zoals de anamnese, het behandelplan, verwijzingen voor onderzoek, onderzoeksuitslagen, het optreden of uitblij-

63 CTG 25 juli 2017, ECLI:NL:TGZCTG: 2017:217, zie ook $\S 2.2$, noot 9 .

64 Zie ook: RTG Den Haag 22 december 2015, ECLI:NL:TGZRSGR:2015:167, r.o. 5.6. ven van bijwerkingen of complicaties, de begeleiding en aantekeningen over communicatie met de patiënt en/of diens naasten over (de voortgang van) het behandeltraject, ontbreekt in de dossiers. Hierdoor is onduidelijk of de experimentele behandeling enig effect heeft (gehad), en zelfs of daar überhaupt onderzoek naar is gedaan. Het RTG verbaast zich er voorts over dat de arts niets heeft genoteerd over voortschrijdende of gewijzigde inzichten. Daardoor geven de dossiers op geen enkele wijze inzicht in het verloop van de behandeling en de overwegingen van de arts daarbij. Anders dan de arts stelt, is het RTG van mening dat eventuele opname van informatie in een biobank onverlet laat dat patiëntgegevens ook in het patiëntendossier moeten worden opgenomen. De conclusie luidt dat het de patiëntendossiers allerminst voldoen aan de daaraan te stellen eisen. Dit neemt het RTG de arts in het bijzonder kwalijk, nu diens bewering dat zijn experimentele behandeling voor patiënten zonder uitzicht op genezing in de reguliere geneeskunde effectief zou kunnen zijn, en dat die effectiviteit opweegt tegen het nadeel van de bijwerkingen, daardoor oncontroleerbaar is. ${ }^{65}$

In deze verslagperiode werden ook regelmatig tuchtprocedures gevoerd waarin het recht op inzage c.q. afschrift aan de orde kwam. Ten aanzien van een klacht over een verzoek tot inzage van een ouder na echtscheiding, overwoog RTG Den Haag dat de huisarts die kennelijk twijfelde aan het gezag, hiervan enig bewijs mocht vragen. Dit is conform de KNMG-artseninfolijn 'Welke informatie mogen (gescheiden) ouders over hun kind(eren) ontvangen?'. Het RTG wijst er voorts op dat beide ouders in geval van gezamenlijk gezag evenveel recht hebben op informatie over de behandeling en de gezondheidstoestand van hun kind. Deze informatie is klager te lang onthouden. Het had op de weg van de huisarts gelegen om binnen een redelijke termijn na het verzoek om het medisch dossier zelf actie te ondernemen. Het RTG geeft in dat kader aan te begrijpen dat de juridische gevolgen van een echt-

65 RTG Den Haag 27 oktober 2015, ECLI:NL:TGZRSGR: 2015:136, GJ 2016/8. 
scheiding op het punt van het ouderlijk gezag niet steeds helder zijn voor een niet-jurist, maar dat de huisarts binnen betrekkelijk korte tijd zelf navraag had moeten doen toen hij daar kennelijk over twijfelde. Daarbij wordt gesteld dat dit tegenwoordig heel eenvoudig kan door raadpleging van de artseninfolijn die door de KNMG digitaal ter beschikking wordt gesteld. De huisarts wordt voorts verweten dat zijn dossiervoering ontoereikend was. Het RTG constateert dat uit de dossiervoering niet duidelijk blijkt wanneer de subjectieve mening van een derde overgaat in het standpunt van de huisarts. Desondanks is het van oordeel dat er geen sprake is van tuchtrechtelijk verwijtbare ontoereikende dossiervoering. Het zou echter wel beter zijn geweest als de arts wat meer nuance zou hebben betracht in de vastlegging van zijn persoonlijke standpunten in het dossier. ${ }^{66}$

Een soortgelijke klacht werd ingediend tegen een fysiotherapeut. Klager (patiënt) verweet de fysiotherapeut dat hij geen afschrift had overgelegd van de gegevens die hij over klager had. De fysiotherapeut erkende dat hij klager geen afschrift heeft verstrekt van het medisch dossier. Hij had ervoor gekozen een brief met daarin de diagnose en informatie over (het verloop van) de behandeling naar de belangenbehartiger van klager te sturen. Zijns inziens kon hij daarmee volstaan. RTG Zwolle verwijst in dit kader naar artikel 7:456 lid 1 BW en stelt dat daarin bepaald is dat de hulpverlener aan de patiënt, desgevraagd, zo spoedig mogelijk inzage in en afschrift van de bescheiden, zoals bedoeld in artikel 7:454 BW, verstrekt. Klager heeft daartoe meerdere verzoeken moeten indienen en ter zitting heeft klager nog steeds geen afschrift van het dossier ontvangen. Het RTG acht het verwijtbaar dat het dossier niet binnen een redelijke termijn en compleet is overgelegd. Daarbij is het niet onredelijk om een vergoeding te vragen voor het verstrekken van een afschrift van het dossier, dat is ook zo opgenomen in de wet. $^{67}$

RTG Den Haag 5 juli 2016, ECLI:NL:TGZRSGR: 2016:75.

67 RTG Zwolle 22 april 2016, ECLI:NL:TGZRZWO: 2016:46
Opmerkelijk was de zaak waarin werd geklaagd over het recht op inzage en de inrichting van het medisch dossier door de psychotherapeut. Het fysieke en digitale dossier ontbrak, zodat daar niet over beschikt kon worden tijdens de zitting. Desondanks gaf RTG Amsterdam aan hier op grond van de stukken en hetgeen partijen ter zitting hebben verklaard, wel een beeld over te kunnen vormen. Het dossier bestond uit minstens 80 dubbelzijdig handgeschreven A4'tjes. Naast de gegevens die nodig zijn in het kader van een goede hulpverlening op grond van artikel 7:454 lid 1 BW bevatte het tevens werkaantekeningen, zoals de psychotherapeut deze noemde. Het RTG overwoog dat het niet geheel duidelijk is geworden waar het onderscheid zit tussen werkaantekeningen en gegevens bestemd en noodzakelijk voor opneming in het medisch dossier. Het dossier van klaagster bestond enkel uit aantekeningen van de consulten, andere gegevens waren daar niet in opgenomen. De psychotherapeut heeft verklaard dat hij, nadat het medisch dossier begin 2011 werd vernietigd en de consulten na enige maanden weer werden gestart, niets meer heeft opgeschreven. Het RTG acht de dossiervorming vér onder de wettelijke en tuchtrechtelijke maat. Een verzameling van handgeschreven A4'tjes zonder enige structuur is volstrekt onvoldoende. Zonder meer laakbaar is dat hij na het weer opstarten van de consulten in het geheel geen dossier meer heeft bijgehouden, daar het medisch dossier immers ook relevant is voor opvolgende hulpverleners of vervangers. De psychotherapeut voerde daaromtrent aan dat hij, indien gewenst, bereid zou zijn geweest om ten behoeve van een opvolgend hulpverlener een samenvatting te maken van de 80 pagina's. Het RTG maakte korte metten met dit verweer en stelde zich op het standpunt dat dit er niet toe zou leiden dat het dossier achteraf 'geheeld' had kunnen worden. Daarbij betrekt het RTG dat de werkwijze van de psychotherapeut het inzagerecht van klaagster frustreert. Toen klaagster verzocht om inzage, stelde de psychotherapeut dat het deels onleesbaar was. Een patiënt heeft echter recht op inzage in diens medisch dossier ex artikel 7:456 BW. Dit behelst eveneens dat het medisch dossier toegankelijk, en 
dus leesbaar, moet zijn. Hoewel de psychotherapeut de gelegenheid heeft geboden om het dossier voor te lezen aan klaagster, is dat niet overeenkomstig de wettelijke plicht om inzage te bieden. ${ }^{68}$

Anders werd geoordeeld over een klacht tegen een orthopeed. Klaagster verweet de orthopeed dat haar decursus onvolledig en slecht leesbaar was. In eerste aanleg werd overwogen dat het handschrift in de decursus zeer slecht leesbaar was. Dat terwijl het de basis en de geheugensteun voor de verdere behandeling is en tevens is bedoeld voor de opvolgende behandelaar. Het RTG stelde voorts dat de decursus, voor zover leesbaar, onvolledig was. In hoger beroep overweegt het CTG echter dat de voor een leek slecht leesbare decursus in samenhang met het röntgenarchief en de correspondentie van de orthopeed moet worden bezien. De decursus is bedoeld voor de opvolgende behandelaar en als geheugensteun voor de verdere behandeling, niet voor de patiënt. Het CTG oordeelde dat de decursus in samenhang met de correspondentie voor de beroepsbeoefenaar voldoende leesbaar is. Niet is gebleken dat er relevante feiten ontbreken in het dossier van klaagster. Het CTG komt dan ook tot de slotsom dat de orthopeed op dit punt geen tuchtrechtelijk verwijt gemaakt kan worden. ${ }^{69}$

Hoewel onvolledige dossiervoering dus tuchtrechtelijk verwijtbaar kan zijn, is het achteraf aanvullen van het dossier in het algemeen in de regel even verwijtbaar. Het CTG behandelde een klacht over een tandarts, die werd verweten achteraf wijzigingen in het patiëntendossier van klager te hebben aangebracht. De schriftelijke stukken bij de behandeling van de zaak bevatten twee dossiers, die inhoudelijk van elkaar verschillen. Toen er een meningsverschil bleek te zijn over de begroting heeft de tandarts een wijziging doorgevoerd in het dossier. Het CTG overwoog dat het in een enkel geval te rechtvaardigen is een dossier later aan te vullen, mits duidelijk wordt aangegeven dat het om een aanvulling gaat en dat de reden ervan vermeld wordt. Hetgeen in casu niet het geval was. Het feit dat de tandarts het medisch dos-

68 RTG Amsterdam 20 september 2016, ECLI:NL: TGZRAMS:2016:62.

69 CTG 1 november 2016, Stcrt. 2016, 60291. sier later, nadat een conflict ontstaan was met klager over de behandeling, inhoudelijk heeft aangepast zonder in het dossier te vermelden wanneer en waarom hij deze wijziging(en) heeft aangebracht, wordt hem door het CTG tuchtrechtelijk zwaar aangerekend. De betreffende wijzigingen hebben mede betrekking op onderdelen van de behandeling waarover het conflict ging. Derhalve kan niet uitgesloten worden dat de tandarts deze heeft aangebracht met het kennelijke oogmerk de wijzigingen als het originele dossier te kunnen presenteren in het kader van het conflict. Met dit handelen heeft de tandarts de betrouwbaarheid van dit essentiële document ernstig aangetast. Het CTG wijst er daarbij op dat een zorgvuldig bijgehouden en betrouwbaar medisch dossier van cruciaal belang is, zowel in het kader van de kwaliteit van de zorgverlening als in situaties waarin een beroepsbeoefenaar verantwoording voor zijn handelen moet afleggen. ${ }^{70}$

RTG Eindhoven oordeelde vergelijkbaar over een klacht tegen een huisarts. Deze werd verweten het dossier op een later tijdstip te hebben aangepast. Nader onderzoek wees uit dat dit inderdaad het geval was, hetgeen het College tuchtrechtelijk verwijtbaar achtte. ${ }^{71}$

Het CTG oordeelde op dezelfde wijze over een soortgelijke klacht tegen een plastisch chirurg. Klaagster verweet hem onzorgvuldige medische verslaglegging / valsheid in geschrifte, omdat hij het risico van necrose achteraf, nadat klaagster haar klachten en onvrede had geuit, alsnog in het medisch dossier had opgetekend. Tevens klaagde zij over onzorgvuldige medische verslaglegging, omdat het operatieverslag ontbreekt. De plastisch chirurg erkent dat hij het dossier heeft aangepast en het risico van necrose achteraf in het medisch dossier heeft genoteerd. Zijn verklaring daaromtrent luidt dat hij de beste bedoelingen had en puttend uit zijn geheugen het dossier wilde completeren. Het CTG acht de intentie waarmee de chirurg heeft gehandeld voor de beoordeling echter niet relevant. Het achteraf aanvullen of wijzigen van een medisch dossier

70 CTG 3 december 2015, Stcrt. 2015, 45179.

71 RTG Eindhoven 19 oktober 2016, ECLI:NL:TGZREIN: 2016:78. 
zonder daarover transparant te zijn is volgens het College eenvoudigweg ontoelaatbaar. Het CTG makkt de plastisch chirurg ter zake een ernstig tuchtrechtelijk verwijt. Hij heeft met zijn handelen niet enkel het vertrouwen van klaagster geschaad, maar ook het vertrouwen dat patiënten in het algemeen moeten kunnen hebben in een volledige en waarheidsgetrouwe weergave van de gang van zaken in het medisch dossier.

Het CTG bevestigde tevens het oordeel van het RTG dat het operatieverslag te summier is, daar de voor het vervolgbeleid benodigde beoordeling van de circulatie in het tepelhofcomplex aan het eind van de operatie daarin ontbreekt. ${ }^{72}$

Van geheel andere aard was de klacht tegen een psychiater die werd verweten dat hij klager (patiënt) onder dwang zou hebben gemanipuleerd om zelf het verslag van het gesprek in het EPD op de computer in te typen. Klager stelt dat hij door deze handelswijze geen goede weergave van het gesprek heeft kunnen geven, omdat hij overrompeld was en dichtklapte. Hij is van mening dat het een ongehoord en vernederend verzoek was en vreest dat het verslag tegen hem wordt gebruikt. Voorts verwijt hij de psychiater dat de door klager oorspronkelijk ingetypte tekst is aangepast en aangevuld. RTG Eindhoven verwijst naar artikel 7:454 BW, waarin de verplichting van een arts is verankerd om een dossier in te richten met betrekking tot de behandeling van de patiënt. Overwogen wordt dat een goede, toegankelijke en begrijpelijke verslaglegging in het medisch dossier van groot belang is, niet alleen voor de kwaliteit en continuiteit van de zorgverlening en begeleiding, maar ook vanwege de verantwoording en toetsbaarheid van het handelen van de desbetreffende hulpverlener. Het dossier moet dus compleet, helder, overzichtelijk en behoorlijk leesbaar zijn en zodanig ingericht zijn dat een (waarnemend) collega-behandelaar zich op korte termijn in het dossier kan inlezen en de behandeling van de patiënt daarop kan afstemmen. Het RTG concludeert dat de psychiater tekort is geschoten in zijn dossierplicht, nu hij klager heeft verzocht om een tekst in het EPD in te typen, waarbij hij geen tekst aan klager heeft gedicteerd of op andere wijze de regie heeft gevoerd met betrekking tot de vorm en inhoud van de verslaglegging. De door klager ingetypte tekst is ook nadien niet in overeenstemming gebracht met de eisen van een goede verslaglegging. Het is bovendien hoogst ongebruikelijk patiënten zelf gegevens in te laten voeren in het EPD. De psychiater overschrijdt hiermee de professionele norm. Daarnaast heeft het tot gevolg dat een complete, heldere en overzichtelijke verslaglegging ontbreekt. Uit de betreffende verslaglegging blijkt immers niet voldoende wat er met klager is besproken en/of wat het afgesproken beleid is. Dit is tuchtrechtelijk verwijtbaar. De psychiater voerde nog aan dat patiënten door zelf te typen hun eigen visie op het gesprek kunnen geven. Indien het van belang wordt geacht de visie van patiënten op het gesprek te noteren, dan dient voor (waarnemend) collega-behandelaren bij het lezen van het medisch-psychiatrische beloop duidelijk te zijn welke opmerkingen van de behandelaar zijn en welke van de patiënt, aldus het CTG. Dat was in casu niet het geval. ${ }^{73}$

Tot slot een klacht over een (gedeeltelijk) zoekgeraakt dossier. Een neuroloog wordt verweten dat de schriftelijke verslaglegging van het ziektebeloop en de behandeling van klaagster in de periode 20 tot en met 23 mei 2010 ontbreekt. Deze nalatigheid heeft voor klaagster grote gevolgen gehad. Zij lijdt aan cognitieve stoornissen. Het CTG stelt primair dat de neuroloog als de behandelend arts van klaagster op grond van artikel 7:454 BW een dossierplicht heeft. Op basis daarvan wordt hij geacht alle gegevens omtrent klaagsters behandeling en gezondheidstoestand in een medisch dossier bij te houden en te bewaren. Het staat vast dat er geen medisch dossier aanwezig is voor de genoemde periode. Het ontbreken van het medisch dossier komt in beginsel voor risico van de neuroloog. Het ligt dan ook op zijn weg om aannemelijk te maken dat hij niet tekortgeschoten is in zijn dossierplicht. In hoger beroep heeft de neuroloog gesteld dat hij zeker weet dat hij

73 RTG Eindhoven 6 februari 2017, ECLI:NL:TGZREIN: 2017:21 anders naar het lijkt: RTG Zwolle 27 juli 2017 (zie § 2.6 en noot 33). 
over de betreffende periode een dossier heeft bijgehouden. Dat het dossier over die periode niet (langer) voorhanden is, acht het CTG buitengewoon kwalijk en ongelukkig'. Het heeft tot gevolg dat het ziektebeloop van klaagster niet (volledig) kan worden gereconstrueerd. De neuroloog heeft daartoe aangevoerd dat hij voor het beheer en opslag van het medisch dossier afhankelijk is van de instelling. Nadat bekend werd dat er een (mogelijke) klacht of gerechtelijke procedure van klaagster was, heeft het medisch dossier een onbestemd traject gevolgd via de juridische afdeling, de neuroloog en uiteindelijk de polikliniekassistente. Daaromtrent heeft de neuroloog aangevoerd dat hij het medisch dossier, na een aanvankelijke retourzending, in tweede instantie toch van de juridische afdeling heeft aangenomen en vervolgens heeft doorgegeven aan een assistente van de polikliniek om het te kopiëren. Hij heeft het medisch dossier daarna niet meer teruggezien. Het CTG kan 'door het niet scherp afgebakende traject dat het medisch dossier kennelijk gevolgd heeft', niet vaststellen of de neuroloog al dan niet persoonlijk tuchtrechtelijk verwijtbaar is tekortgeschoten ter zake. De slotsom luidt dan ook dat het CTG het de neuroloog in dit specifieke geval niet tuchtrechtelijk verwijt dat het medisch dossier over bedoelde periode niet meer voorhanden is. ${ }^{74}$

\section{Voorbehouden handelingen}

In deze verslagperiode zijn slechts enkele uitspraken gedaan over voorbehouden handelingen. ${ }^{75}$ Opmerkelijk was een klacht van de Inspectie tegen een huisarts die een labiareductie in zijn huisartsenpraktijk had uitgevoerd. RTG Zwolle stelt zich primair de vraag of de huisarts deze ingreep wel had mogen verrichten. Naar het oordeel van het College is het verdedigbaar dat de huisarts, gelet op zijn meerjarige ervaring met gangbare kleine chirurgische ingrepen in zijn praktijk alsmede zijn ervaringen met bevallingen, zich technisch in staat achtte om de betreffende ingreep uit te voeren, maar dat houdt nog niet in dat de huisarts daartoe ook bekwaam was in de zin van artikel 36, lid 1 jo. lid 15 Wet BIG. Het RTG betrekt daarbij dat de huisarts deze specifieke ingreep in totaal slechts vijfmaal had uitgevoerd, en in de afgelopen dertig jaar slechts drie- à viermaal. De huisarts had zich derhalve moeten realiseren dat hij niet bekwaam en derhalve niet bevoegd was om deze ingreep uit te voeren. ${ }^{76}$

In een zaak waarin geklaagd werd over een tandarts, besteedde RTG Den Haag aandacht aan het in opdracht geven van voorbehouden handelingen en de daarvoor geldende voorwaarden. De tandarts werd verweten dat de bij hem werkzame tandartsassistente, voor wiens handelen hij verantwoordelijk was, op een onzorgvuldige en pijnlijke wijze een verdoving had geplaatst met pijn en schade tot gevolg. Het geven van een injectie ten behoeve van lokale anesthesie is een voorbehouden handeling in de zin van artikel 36 Wet BIG, tot de uitvoering waarvan alleen de tandarts zelfstandig bevoegd is, aldus het RTG. Deze kan een assistente, dat wil zeggen een hulpverlener die niet zelfstandig bevoegd is en ook geen functionele zelfstandigheid heeft, opdracht geven deze handeling te verrichten. Vereist is dan wel dat wordt voldaan aan de in artikel 38 Wet BIG genoemde voorwaarden. Zo moet degene die de opdracht krijgt daarvoor voldoende bekwaam zijn, moeten er zo nodig aanwijzingen worden gegeven over de uitvoering, moet er toezicht door de tandarts zijn en moet de mogelijkheid van diens tussenkomst voldoende zijn verzekerd. In casu was volgens het RTG voldaan aan deze vereisten nu de assistente over de benodigde opleiding beschikte, de behandeling frequent uitvoerde en de tandarts in de naastgelegen kamer aanwezig was en dus indien nodig beschikbaar. Dat er mogelijk verkeerd was geprikt door de assistente was de tandarts niet tuchtrechtelijk te verwijten. Dat zou enkel anders kunnen zijn indien de tandarts had moeten weten dat de assistente niet bekwaam was voor het geven van het betreffende type verdoving. ${ }^{77}$

76 RTG Zwolle 3 juni 2016, ECLI:NL:TGZRZWO:2016: 60.

77 RTG Den Haag 1 november 2016, ECLI:NL: TGZRSGR:2016:109. 


\section{Bevoegd en bekwaam}

Naast de bovengenoemde uitspraken was er in deze verslagperiode ook een aantal klachten omtrent bevoegdheid en bekwaamheid, zonder dat daarbij sprake was van voorbehouden handelingen.

Zo werd het een plastisch chirurg verweten dat zij de organisatie van de nazorg na een operatie ter verwijdering van borstprothesen niet op orde had. Het CTG overwoog dat, gelet op de jarenlange ervaring van de (recovery-)verpleegkundige, de plastisch chirurg mocht afgaan op diens oordeel dat er geen sprake was van een acute situatie. De (recovery-)verpleegkundige heeft voorts geassisteerd bij de hersteloperatie volgend op de verwijdering van de borstprothesen bij patiënte. Zij heeft daarbij de spreidhaak vastgehouden en benodigdheden, waaronder hechtdraad, aangereikt. Het CTG gaat er daarbij van uit dat de (recovery-)verpleegkundige niet op de hoogte was van de geldende hygiëneregels. Of de hygiëneregels al dan niet zijn gevolgd heeft het CTG niet kunnen vaststellen. De slotsom is echter dat de (recovery-)verpleegkundige 'niet bevoegd of bekwaam' was om bijstand te verlenen bij de betreffende hersteloperatie. ${ }^{78}$

Een andere klacht in deze categorie zag op de bevoegdheid van een basisarts, werkzaam bij het UWV, om een keuring te verrichten nu zij geen verzekeringsarts was. Zij zou volgens klager onbevoegd zijn medische oordelen en adviezen te geven. De basisarts in kwestie verrichtte reeds geruime tijd haar werkzaamheden voor het UWV en voorgangers van deze instelling. Toen de specialisatie verzekeringsarts werd vereist, is zij onder supervisie van een verzekeringsarts gaan werken. Sindsdien worden haar rapporten door haar supervisor beoordeeld en, bij diens instemming, mede ondertekend. De basisarts handelt door deze wijze van werken niet onbevoegd, aldus RTG Den Haag. ${ }^{79}$

Met een klacht over de bekwaamheid van een vijfdejaars arts-assistent in opleiding tot gynaecoloog om sterilisatieoperaties uit te voeren, maakte RTG Eind-

78 CTG 19 mei 2016, ECLI:TGZCTG:2016:188.

79 RTG Den Haag 14 juni 2016, 2015-194, Stcrt. 2016, 64883. hoven korte metten. De arts, inmiddels gynaecoloog, was bekwaam om de ingreep zelfstandig uit te voeren onder beperkte supervisie. In het algemeen moet worden geoordeeld dat een vijfdejaars artsassistent in opleiding tot gynaecoloog met ervaring in sterilisatieoperaties, bekwaam moet worden geacht om een sterilisatie uit te voeren. Zij was door haar opleiders bekwaam verklaard om deze zelfstandig, onder beperkte supervisie, uit te voeren. Het RTG concludeert dat de arts-assistent, gezien haar reeds opgedane ervaring, bekwaam was om de betreffende sterilisatie uit te voeren en dat haar supervisor tijdens de ingreep op de OK aanwezig was. $^{80}$

Ook interessant zijn twee klachten tegen twee verloskundigen, die betrekking hebben op een en dezelfde kwestie. De ene verloskundige hield een verloskundigenpraktijk. De andere verloskundige nam waar voor een collega die met zwangerschapsverlof was. Klaagster (patiënte) verwijt de waarnemend verloskundige dat zij haar had moeten zeggen dat zij niet bevoegd was om echo's te verrichten. Zij had enkel een minor gevolgd waarbij zij had geleerd om de ligging van de foetus tussen 20-30 weken van de zwangerschap te bepalen. Deze minor is niet vergelijkbaar met de post-hbo-cursus Verloskundige Echografie die tot echobevoegdheid leidt, aldus RTG Zwolle. De verloskundige heeft een tiental vitaliteitsecho's gemaakt en samen met haar beoordeeld, waarna deze zelfstandig vitaliteitsecho's mocht verrichten. Dat leidt echter niet tot voldoende bekwaamheid om deze echo's zelfstandig te maken. ${ }^{81}$

Anderzijds werd de praktijkhoudend verloskundige verweten dat zij echo's heeft laten uitvoeren door een daartoe onbevoegde waarnemer. Relevant achtte het RTG dat de verloskundige zich niet op de hoogte had gesteld van de inhoud van de minor die de waarnemer had gevolgd had. Zij had niet louter mogen afgaan op de informatie die de waarnemend verloskundige daarover had verstrekt, maar had

80 RTG Eindhoven 20 juli 2016, ECLI:NL:TGZREIN: 2016:62.

81 RTG Zwolle 12 mei 2017, ECLI:NL:TGZRZWO: 2017:89. 
zichzelf hiervan op de hoogte moeten stellen. Het certificaat, dat de verloskundige niet heeft opgevraagd, had haar al op het spoor kunnen zetten van de beperkte omvang van de minor. Zij had dan ook niet mogen toestaan dat de waarnemer zelfstandig vitaliteitsecho's verrichtte. ${ }^{82}$

In een andere zaak werd een tandarts verweten dat zij het spoelen van wortelkanalen had overgelaten aan een daartoe niet bevoegde en niet bekwame tandartsassistente. Het CTG stelde ter zake primair dat het spoelen van een wortelkanaal geen voorbehouden handeling is in de zin van artikel 36 Wet BIG. Dat betekent niet dat het geen ingrijpende of risicovolle handeling is. Alleen een persoon die daartoe bekwaam is, mag deze handeling uitvoeren. Voor de beantwoording van de vraag of de assistente daartoe bekwaam was, overwoog het CTG dat vastgesteld diende te worden over welke kennis en vaardigheden zij beschikte. Relevant in dat kader achtte het College dat de assistente bij andere tandartsen niet eerder wortelkanalen had gespoeld; dat, hoewel zij zeer ervaren was, zij vier jaar voorafgaand aan haar indiensttreding bij de aangeklaagde tandarts niet als tandartsassistente werkzaam was geweest; dat het incident plaatsvond op haar elfde werkdag; dat de tandarts haar in een periode van elf dagen had opgeleid om wortelkanalen te spoelen, hetgeen voor de assistente nieuw werk was; deze opleiding de bestudering betrof van de anatomie van de kies, oefenen, meekijken bij de tandarts en tweemaal onder begeleiding van de tandarts spoelen; dat de tandarts de assistente niet heeft gewezen op de relevante risico's en haar ook heeft niet verteld wat er moest gebeuren als een patiënt zou klagen over pijn; dat de instructie van de tandarts aan de assistente was om klaagster te blijven spoelen tot de tandarts terug zou komen; en dat voorafgaand aan het incident de assistente eenmaal zelfstandig een wortelkanaal had gespoeld. Voorts heeft het CTG zijn bedenkingen bij de dikte van de naald waarmee de assistente diende te werken. Alles overziende kwam het College tot de conclusie dat de kennis en

82 RTG Zwolle 12 mei 2017, ECLI:NL:TGZRZWO: 2017:90, Stcrt. 2017, 41736. vaardigheden van de assistente tekortschoten en dat zij dus niet bekwaam was om zelfstandig wortelkanalen te spoelen. ${ }^{83}$

Tot slot een klacht over een huisarts die werd verweten dat hij een apothekersassistente 'gesteelde fibroompjes' (steelwratjes) had laten verwijderen. De apothekersassistente had hier geen ervaring mee en voerde de behandeling uit zonder dat hierop enig toezicht werd gehouden. De huisarts erkende dat de apothekersassistente alleen ervaring had met de behandeling van gewone wratten. Hij had haar geïnstrueerd zich daar ook toe te beperken. Met het uitvoeren van de betreffende behandeling is zij dus buiten haar bevoegdheden getreden, aldus de huisarts. Volgens RTG Groningen diende te worden beoordeeld hoe goed de apothekersassistente was geïnstrueerd en hoe het zover heeft kunnen komen dat zij een onjuiste behandeling heeft uitgevoerd. De apothekersassistente was meerdere keren aanwezig geweest bij het aanstippen van wratten door de huisarts. Zij heeft daardoor geleerd hoe ze dat zelf moest doen. De huisarts had de apothekersassistente geïnstrueerd hem erbij te halen als ze het niet vertrouwde. $\mathrm{Zij}$ is niet anwezig geweest bij de behandeling van gesteelde fibroompjes. Mogelijk wist zij dus niet wat het verschil was tussen gesteelde fibroompjes en wratten en zag zij dus ook geen aanleiding om de huisarts erbij te halen. Het RTG overwoog dat het zorgvuldiger was geweest als de huisarts niet alleen instructies zou hebben gegeven over wat zij wel mocht doen, maar ook over wat ze juist niet mocht doen. De behandeling van gesteelde fibroompjes werd normaliter uitgevoerd door de spreekuurondersteuner. Deze laatste had de behandeling volgens de huisarts overgelaten aan de apothekersassistente. Het RTG komt tot de conclusie dat de huisarts met zijn personeel niet voldoende duidelijk heeft afgesproken wie wat mocht doen en welke werkzaamheden aan wie mochten worden gedelegeerd. Tevens hield hij onvoldoende toezicht op wat er in zijn praktijk gebeurde en of behandelingen wel goed werden uitgevoerd. Dat heeft tot gevolg gehad dat een bekwame noch bevoegde apo- 
thekersassistente een onjuiste diagnose stelde bij een patiënt en vervolgens een verkeerde behandeling uitvoerde zonder dat de huisarts op enig moment ingreep. Deze verwijtbare gang van zaken is de huisarts tuchtrechtelijk aan te rekenen nu het valt onder zijn verantwoordelijkheid. In hoger beroep heeft de huisarts zijn beroep ingetrokken, waardoor het oordeel van RTG Groningen overeind blijft. $^{84}$

\section{Samenwerking}

In CTG 19 januari 2016 wordt een patiënt (ook zelf arts) aan een nekhernia geopereerd door een artsassistent. Hij klaagt daarover de neurochirurg aan. Was de patiënt voldoende geïnformeerd over de mogelijkheid dat de ingreep kon worden uitgevoerd door een arts-assistent? Het Centraal Tuchtcollege is van oordeel dat de neurochirurg op basis van de uitgereikte folders ervan mocht uitgaan dat de patiënt op dit punt voldoende was geïnformeerd. Voorts overweegt het College dat de arts-assistent ten tijde van de operatie in de laatste fase van zijn opleiding zat, dat hij bevoegd en bekwaam was de operatie uit te voeren en dat hij dat ook naar behoren zonder complicaties heeft gedaan. Voorts staat vast dat de neurochirurg en de arts-assistent voorafgaand aan de operatie gezamenlijk het medisch dossier van de patiënt hebben doorgenomen en besproken, dat de arts-assistent de discussie die hij voorafgaand aan de operatie nog kort met de patiënt heeft gevoerd, heeft teruggekoppeld naar de neurochirurg en dat de ingreep vervolgens heeft plaatsgevonden onder supervisie van de neurochirurg en dat deze tijdens twee essentiële fasen van de operatie ook daadwerkelijk heeft gesuperviseerd. Het Centraal Tuchtcollege leidt hieruit af dat de neurochirurg de patiënt niet alleen voldoende over de operatie heeft geïnformeerd, maar dat hem ook anderszins niet tuchtrechtelijk kan worden verweten dat de operatie door de arts-assistent is uitgevoerd. Wel was het wenselijk geweest als de neurochirurg zich voorafgaand aan de operatie samen met de arts-assistent aan klager zou hebben gepresenteerd, aldus het CTG. ${ }^{85}$

Tegen een psychiater was een klacht ingediend door de vader en de broer van een patiënt die door suïcide om het leven was gekomen. De klacht dat de psychiater nooit had onderkend dat patiënt aan psychoses leed, faalt. Wat betreft zijn rol als hoofdbehandelaar gaat RTG Eindhoven uit van de vaste jurisprudentie van het CTG op dit punt (CTG 1 april 2008, TvGR 2008/32). Het College is van oordeel dat hij is tekortgeschoten in de regievoering over de informatieverstrekking aan de familie. Ook is hij onvoldoende proactief geweest en tekortgeschoten in het voeren van de regie over en het op de juiste wijze aansturen van de teamleden, met name de verpleegkundige. Het College volgt de psychiater niet in zijn standpunt dat hij als hoofdbehandelaar niet verantwoordelijk kan worden gehouden voor het handelen van de familievertrouwenspersoon. Overwogen wordt verder nog dat de verpleegkundige zelf tuchtrechtelijk verantwoordelijk is voor de uitlatingen zij heeft gedaan naar de familie. ${ }^{86}$

Bij een zwangerschapsduur van 41 weken stelt een verloskundige een te lage hartactie vast. $\mathrm{Zij}$ verwijst de zwangere naar het ziekenhuis. Een cardiotocogram (CTG; hartfilmpje van de baby) wordt gemaakt. Dit neemt alles bij elkaar twee uur in beslag. In overleg met de gynaecoloog volgt dan een spoedsectio. Het kind overlijdt echter de volgende dag. De ouders dienen bij RTG Zwolle tegen de gynaecoloog als supervisor en tegen twee arts-assistenten een klacht in. Op 29 april 2016 deed het College uitspraak. Volgens het RTG heeft de gynaecoloog zich onvoldoende rekenschap gegeven van zijn taak om de regie te voeren over de bevalling van klaagster en daarbij naar behoren supervisie te houden over de assistenten en de uitvoering van de aan hen opgedragen handelingen (berisping) ${ }^{87}$ Een van de twee arts-assistenten was onervaren en nog in haar inwerkperiode. Haar kon niet worden verwe-

85 ECLI:NL:TGZCTG:2016:39, Medisch Contact 2016, 31-32, p. 42-45, GJ 2016/102, m.nt. J.C.J. Dute.

86 RTG Eindhoven 25 januari 2016, ECLI:NL:TGZREIN: 2016:7.

87 ECLI:NL:TGZRZWO:2016:47. 
ten dat zij naar aanleiding van het hartfilmpje onvoldoende actie had ondernomen. Zij was bevoegd noch bekwaam om zelfstandig zonder supervisie een CTG te beoordelen (klacht afgewezen).$^{88}$ De meer ervaren arts-assistent (tien maanden aldaar werkzaam) krijgt echter een waarschuwing opgelegd. Hoewel de gynaecoloog eindverantwoordelijk was, is het College desondanks van oordeel dat de arts-assistent, gelet op haar ervaring, ook een eigen verantwoordelijkheid had. Zij had ervoor moeten zorgdragen dat het CTG tijdig werd beoordeeld en besproken met de gynaecoloog. Er was sprake van onvoldoende afstemming en ontoereikende instructies. ${ }^{89}$

Een basisarts, werkzaam op het terrein van de ouderenzorg, wordt aangeklaagd omdat hij een patiënte met dementie te hoge doseringen van een bepaald medicijn (Metformine) zou hebben gegeven. Daardoor is ze langzaam uitgedroogd en versuft geraakt. Ook door andere medicatie (Seroquel en Exelon) zou haar situatie zijn verslechterd. Verder zou de communicatie tussen de artsen en met de familie tekort hebben geschoten. Het CTG is op 26 mei 2016 van oordeel dat de arts onvoldoende invulling heeft gegeven aan zijn taak als hoofdbehandelaar van patiënte. Van de arts had een meer proactieve houding verwacht mogen worden, aldus het CTG. Hij heeft er onvoldoende blijk van gegeven dat hij een weloverwogen medisch beleid heeft gevoerd en dat regelmatig heeft gemonitord en geëvalueerd. Ook is niet gebleken dat de arts bij de behandeling van patiënte voldoende de regie heeft genomen en in voldoende mate heeft zorggedragen voor de aansturing van de artsen waarvoor hij als supervisor verantwoordelijk was en voor de continuiteit van de zorg aan patiënte. De arts heeft bij zijn handelen de wijze waarop hij behoorde te communiceren met zowel de artsen waarvoor hij als supervisor verantwoordelijk was, als de familie van patiënte veronachtzaamd (berisping)..$^{90}$

In CTG 4 oktober 2016 stelde het College voorop dat de angeklaagde arts, nu hij operatieruimte ter

88 ECLI:NL:TGZRZWO:2016:48.

89 ECLI:NL:TGZRZWO:2016:49; GJ 2016/91.

90 ECLI:NL:TGZCTG:2016:196. beschikking had laten stellen aan een collega-arts (een mond-, kaak- en aangezichtschirurg), enkele weken vóór de operatie klaagster in consult had gesproken, aanwezig was geweest bij de operatie en de aanvankelijke nazorg heeft verricht, in die fase als medebehandelaar dient te worden aangemerkt. Echter, met de collega-arts (als hoofdbehandelaar) had klaagster besproken en afgesproken wat wel of niet geopereerd zou worden en in die keuze was geen beslissende of medebeslissende rol voor de arts weggelegd. Hem treft dan ook geen verwijt ten aanzien van de vraag of de operatie bij klaagster is uitgevoerd zoals deze met haar is besproken. ${ }^{91}$

Een apotheker maakt bij de controle van de medicatie een fout (onjuiste dosering), waarvoor de beherend apotheker wordt aangeklaagd. Het Tuchtcollege in eerste aanleg oordeelt dat de beherend apotheker 'onder omstandigheden wel verantwoordelijk kan worden gehouden voor het eventueel handelen/nalaten van haar medewerkers', maar in casu was van een structurele tekortkoming in de werkwijze van de apotheek geen sprake. De procesinrichting was goed, maar in het geval van patiënte niet goed uitgevoerd. Het werkproces hoefde niet te worden aangepast. Ook het CTG is van oordeel dat de beherend apotheker persoonlijk geen verwijt kan worden gemaakt. ${ }^{92}$

Klaagster was onder behandeling voor een tumor in haar rechterborst. Zij werd bestraald met behulp van een elektronenmal, maar door een verwisseling van mallen is zij twaalf keer met een verkeerde mal bestraald. De radiotherapeut, hoofd van de afdeling radiotherapie, wordt verweten dat de - inmiddels aangepaste - protocollen destijds niet voldeden. RTG Zwolle overweegt op 24 februari 2017 dat de enkele omstandigheid dat de protocollen zoals die golden ten tijde van de behandeling van klaagster niet als onvoldoende zijn beoordeeld door de visitatiecommissie van de eigen wetenschappelijke vereniging en/of door de Joint Commision International (JCI) in het kader van de JCI-accreditatie, niet met

91 ECLI:NL:TGZCTG:2016:304. Ook de collega-arts werd aangeklaagd: ECLI:NL:TGZCTG:2016:304.

92 CTG 15 november 2016, ECLI:NL:TGZCTG:2016:338, Medisch Contact 2017, 13, p. 30-32. 
zich brengt dat reeds om die reden geoordeeld dient te worden dat de protocollen voldoen aan de daaraan in redelijkheid te stellen eisen. Het College is verder van oordeel dat het protocol destijds op het onderdeel van de identificeerbaarheid van de patiënt tekortschoot, welk tekortschieten van invloed kan zijn op de individuele gezondheidszorg. Verweerder is daarvoor in tuchtrechtelijke zin verantwoordelijk (waarschuwing). ${ }^{93}$

In CTG 24 november 2015 had het Tuchtcollege in eerste aanleg naar aanleiding van een klacht van de IGZ een internist berispt onder meer omdat hij als hoofdbehandelaar en supervisor van een (derdejaars) arts-assistent op cruciale punten verwijtbaar tekortgeschoten was ten aanzien van een vitaal bedreigde leukemiepatiënte, die kort daarna overleed. Het CTG dacht daar anders over. Er waren geen aanwijzingen dat de arts in het onderhavige geval in een van beide rollen niet adequaat had gehandeld. Op een bepaald moment had de internist aan de arts-assistent aangegeven dat de intensivist moest worden opgeroepen om patiënte te beoordelen. Het oproepen van een intensivist om mede te beoordelen of een patiënt overgeplaatst moet worden naar een IC is een handeling die in het algemeen - en ook in dit specifieke geval - aan een derdejaars arts-assistent kan worden overgelaten, aldus het CTG. De internist had voorts verklaard dat een opgeroepen intensivist als regel direct naar de patiënt komt en dat daarbij geen rol speelt of het verzoek afkomstig is van een opleider/supervisor dan wel van een artsassistent. ${ }^{94}$

In zijn beslissing van 21 juni 2016 overwoog het CTG dat er gedurende een behandeling steeds maar één hoofdbehandelaar is. Wel kan in het behandeltraject een wisseling van het hoofdbehandelaarschap optreden. Het CTG is in casu van oordeel dat de aangeklaagde chirurg als hoofdbehandelaar niet tuchtrechtelijk verwijtbaar onzorgvuldig heeft gehandeld. Wel merkt het College op dat hij zijn taak als hoofdbehandelaar een ruimere invulling had kunnen geven. Blijkbaar zag de chirurg zijn rol als hoofdbehandelaar vooral als degene die op essentiële (medische) beslismomenten 'de knoop doorhakt' en zo richting geeft aan het verdere verloop van de behandeling, dit terwijl de hoofdbehandelaar geacht wordt ook oog te hebben voor de meer perifere medische aspecten van de behandeling van de patiënt (zoals diens geestelijk welzijn en de algehele voortgang) en hij daarnaast fungeert als centraal aanspreekpunt voor de patiënt en diens naaste betrekkingen. In dit verband wordt hij als hoofdbehandelaar geacht voldoende informatie te (doen) verstrekken over (het verloop van) de behandeling en eventuele vragen tijdig en adequaat te (doen) beantwoorden)..$^{95}$

In zijn uitspraak van 2 februari 2017 oordeelde het CTG dat de aangeklaagde arts en psychotherapeut, anders dan deze betoogde, de hoofdbehandelaar van de dochter van klager was. De dochter werd behandeld door een niet-BIG-geregistreerde kindertherapeut die door een zorgmakelaar was gekoppeld aan de arts. Ter zitting had de arts verklaard dat hij gedurende de behandeling van de dochter van klager een diagnose heeft gesteld en die diagnose aan de zorgmakelaar heeft doorgegeven, als gesprekspartner van de therapeut is opgetreden, de therapeut heeft geadviseerd, inzicht in het dossier heeft gehad en aantekeningen in het dossier heeft laten opnemen. Voorts heeft de arts verklaard dat hij in het kader van de behandeling DBC-houder is geweest en heeft gedeclareerd bij de zorgmakelaar. Het CTG overweegt dat hij niet heeft kunnen uitleggen wat het hoofdbehandelaarschap inhoudt. Van de Handreiking Verantwoordelijkheidsverdeling bij samenwerking in de zorg van januari 2010 en van de jurisprudentie van het CTG ter zake bleek hij niet op de hoogte. Hij gaf aan 'de veldnorm' niet te kennen en kon evenmin uiteenzetten wat het verschil was tussen supervisie en werkbegeleiding. De arts heeft zijn taak als hoofdbehandelaar schromelijk verwaarloosd door daaraan geen enkele invulling te geven, aldus het CTG. Van enige regie met betrekking tot de behandeling van de dochter van klager was niet gebleken. Ook op andere onderdelen was 
de arts tekortgeschoten, met ernstige gevolgen voor klager. De inschrijving in het register als zowel arts als psychotherapeut wordt daarom doorgehaald. ${ }^{96}$ In een zaak waarover RTG Den Haag op 7 maart 2017 oordeelde, was een in palliatieve zorg gespecialiseerde anesthesioloog, aanvankelijk als vriend, betrokken geraakt bij de behandeling van een ernstig zieke patiënt. Hem werd verweten dat hij de huisarts niet had geïnformeerd over de medicatie die hij had voorgeschreven (morfine en haldol). De klacht was ingediend door de IGZ. Vaststond dat de patiënt geen toestemming had gegeven voor het verstrekken van informatie aan de huisarts. Vervolgens overweegt het College dat het medisch beroepsgeheim niet betekent dat een andere behandelaar, in casu de huisarts, helemaal niet geïnformeerd kan of moet worden. 'Uitgangspunt is dat wordt samengewerkt, dan wel tenminste wordt geïnformeerd, wanneer sprake is van gelijktijdige behandeling door verschillende behandelaren. Het medisch beroepsgeheim strekt niet zo ver dat patient zijn behandelaar kan verbieden contact te hebben met, in dit geval, de huisarts, die patiënt tot aan zijn overlijden heeft behandeld. Dat geen medische informatie aan de huisarts verstrekt kon worden, laat onverlet dat verweerder in dit geval had moeten zoeken naar een wijze om informatie te verstrekken zonder het beroepsgeheim te schenden dan wel naar een handelwijze om de bestaande situatie te doorbreken.' Dat had de anesthesioloog onvoldoende gedaan en levert hem een waarschuwing op. ${ }^{97}$ Helaas zegt het College er niet bij wat de anesthesioloog zoal had kunnen doen.

Op 21 maart 2017 deed RTG Amsterdam uitspraak in een zaak waarin de IGZ een longarts verweet dat hij als supervisor en hoofdbehandelaar is tekortgeschoten in de medische zorg voor een jonge patiënt, die vervolgens overleed. Het College neemt het de arts kwalijk dat hij, in zijn rol van superviserend specialist, de fysieke beoordeling van patiënt volledig heeft overgelaten aan een arts-assistent, die pas vier maanden als zodanig werkte. De longarts was

96 ECLI:NL:TGZCTG:2017:53, Stcrt. 2017, 7613.

97 Stcrt. 2017, 36086. niet op de locatie aanwezig voor overleg en had zelf spreekuur. Hij had de patiënt, met een onduidelijk klinisch beeld met evidente laboratoriumafwijkingen en een niet-pluisgevoel bij de SEH verpleegkundige en de arts-assistent, zelf moeten zien of laten beoordelen door een collega-specialist. Hij krijgt hiervoor een waarschuwing. Daarbij overweegt het College onder meer het volgende. 'Opvallend is dat alleen verweerder zich voor het college heeft moeten verantwoorden, terwijl in deze zaak verschillende andere zorgverleners, al dan niet in een bestuurlijke rol, bij de zorg voor patiënt waren betrokken en tegen wie geen tuchtklacht is ingediend.' Volgens het College 'heeft in deze zaak het organisatiemodel van het ziekenhuis een belangrijke rol gespeeld. Het management van zorginstellingen is wettelijk eindverantwoordelijk voor de kwaliteit en veiligheid van de zorg. Uit oogpunt van normstelling en kwaliteitsbevordering c.q. bewaking, acht het college het wenselijk dat IGZ niet een (te) strikt selectiebeleid hanteert waar het gaat om het voorleggen van zaken aan de tuchtrechter. Door uitsluitend het handelen van verweerder ter toetsing voor te leggen komt het college niet toe aan een integrale (tuchtrechtelijke) beoordeling van het medisch en bestuurlijk handelen in dezen. Aldus kan maar ten dele invulling worden gegeven aan het tuchtrecht als 'kwaliteitsinstrument van de gezondheidszorg. ${ }^{98}$ Een niet mis te verstane vingerwijzing voor de IGZ.

\section{Medische rapportages}

In de verslagperiode zijn er veel uitspraken gedaan over medische rapportages. De standaarduitspraak daarvoor is CTG 30 januari 2014, waarin het College zijn eerdere jurisprudentie op dit punt aanscherpt. ${ }^{99}$ Een rapportage wordt sindsdien getoetst aan de volgende criteria:

1 het rapport vermeldt de feiten, omstandigheden en bevindingen waarop het berust;

98 Stcrt. 2017, 26037.

99 ECLI:NL:TGZCTG:2014:17, TvGR 2014/18, m.nt. J.C.J. Dute. 
2 het rapport geeft blijk van een geschikte methode van onderzoek om de voorgelegde vraagstelling te beantwoorden;

3 in het rapport wordt op inzichtelijke en consistente wijze uiteengezet op welke gronden de conclusies van het rapport steunen;

4 het rapport vermeldt de bronnen waarop het berust, daaronder begrepen de gebruikte literatuur en de geconsulteerde personen;

5 de rapporteur blijft binnen de grenzen van zijn deskundigheid.

Daarbij wordt ten volle getoetst of het onderzoek door de arts uit het oogpunt van vakkundigheid en zorgvuldigheid de tuchtrechtelijke toets der kritiek kan doorstaan. Ten aanzien van de conclusies van de rapportage wordt beoordeeld of de arts in redelijkheid tot zijn conclusie heeft kunnen komen.

Dit stramien geeft de tuchtcolleges een duidelijke kapstok voor de beoordeling van medische rapportages. Vaak worden de verschillende elementen van het toetsingskader nauwkeurig langsgelopen.

Een gz-psycholoog had in het kader van een vordering tot verlenging van de tbs-maatregel van klager in opdracht van het NIFP een zogenoemde zesjaarsrapportage opgesteld. Volgens klager had hij bepaalde stukken, met name een beslissing van het gerechtshof en enkele pro justitia rapportages, niet bij zijn onderzoek betrokken. RTG Eindhoven oordeelde dat hij wel de beschikking had gehad over de beslissing van het gerechtshof en dat het rapport dus niet alle bronnen vermeldt waarop het berust. Om de pro justitia rapportages had de gz-psycholoog het NIFP vergeefs verzocht. Door in zijn rapportage niet aan te geven dat hij niet beschikte over deze stukken en welke stappen hij had ondernomen om ze te verkrijgen, voldeed de rapportage niet aan de eis dat het volledig de feiten, omstandigheden en bevindingen vermeldt waarop het berust. Verder verwijst het RTG naar artikel 4.5 Gedragscode van het Nederlands Register Gerechtelijk Deskundigen dat bepaalt dat de deskundige binnen de reikwijdte van zijn opdracht persoonlijk al het noodzakelijke onderzoeksmateriaal verzamelt of dit (mede) onder zijn verantwoordelijkheid laat doen. Nu de gz-psy- choloog dat ten aanzien van de pro justitia rapportages niet had gedaan, werd ook niet voldaan aan de eis dat het rapport blijk geeft van een geschikte methode van onderzoek om de voorgelegde vraagstelling te beantwoorden. Het RTG stelt dat 'onzorgvuldig handelen in een situatie als de onderhavige waarin het gaat over verlenging van vrijheidsbeperkende maatregel - een ernstig gegeven is', maar legt toch slechts een waarschuwing op. Het CTG verwerpt het ingestelde beroep. Dat het bewuste artikel in de gedragscode inmiddels geherformuleerd is (de deskundige dient om opheldering te vragen bij onduidelijkheid in de opdracht) maakt dit niet anders. Die norm gold ten tijde van het litigieuze handelen van de gz-psycholoog nog niet en bovendien had ook de nieuwe norm hem niet ontslagen van de verplichting nadere informatie op te vragen. ${ }^{100}$

Een andere gz-psycholoog maakte het zo bont, dat RTG Eindhoven - in een betrekkelijk korte uitspraak - tot de conclusie kwam dat diens rapportage 'getoetst aan de bovenvermelde criteria, op alle onderdelen schromelijk tekortschiet'. De rapportage had betrekking op een drietal rapporten van de Raad voor de Kinderbescherming over de vraag wat het hoofdverblijf van een kind moest zijn waarvan de ouders in een echtscheidingsprocedure verwikkeld waren. Het College beperkt zich tot 'enkele van de meest ernstige tekortkomingen' zoals: 'De conclusie die verweerder trekt kan volstrekt niet worden gebaseerd op zijn rapportage.' Volgens het College komt het 'zelden voor dat een rapport zo ver onder de maat is'. Het schorst de inschrijving van de gz-psycholoog in het register voor de duur van een maand. ${ }^{101}$

Verweerster, CIZ-arts, had twee medische adviezen uitgebracht in het kader van een aanvraag voor een indicatie voor AWBZ-zorg. Het CTG sluit zich aan bij RTG Amsterdam dat de adviezen voldoen aan het boven beschreven kader. Voorts werd overwogen: 'In het bijzonder is het zien van de patiënt niet noodzakelijk. Wel dient te worden gemotiveerd

100 CTG 18 mei 2017, Stcrt. 2017, 34376.

101 RTG Eindhoven 1 februari 2016, Stcrt. 2016, 15327. 
waarom verder onderzoek achterwege kan blijven. Dat is hier ook gebeurd: het was onnodig belastend voor klaagster, er was voldoende relevante informatie, er bestond geen twijfel over de aard en de ernst van het ziektebeeld.' Het CTG voegt daar nog aan toe dat de arts niet degene is geweest die in eerste instantie de indicatieaanvraag heeft beoordeeld. De arts is pas betrokken geraakt nadat klaagster bezwaar en beroep tegen het door het CIZ vastgestelde indicatiebesluit had ingesteld. Bezien tegen deze achtergrond kon en mocht de arts zich baseren op de ten tijde van het indicatiebesluit reeds in het CIZ-dossier aanwezige medische gegevens en was nader medisch onderzoek van klaagster niet noodzakelijk. ${ }^{102}$

Een psychotherapeut had op verzoek van de expartner van klaagster, met wie hij in een 'vechtscheiding' lag, een second opinion uitgebracht over een eerdere rapportage over hun dochter, opgesteld door een GGZ-organisatie. Het CTG overwoog dat duidelijk was dat de ex-partner het rapport van de psychotherapeut zou inbrengen in het kader van de echtscheidingsprocedure. In deze omstandigheden acht het Centraal Tuchtcollege het uitbrengen van een second opinion door een onafhankelijke beroepsbeoefenaar geoorloofd. Wel is dan terughoudendheid geboden. Die terughoudendheid had er in de gegeven omstandigheden uit kunnen bestaan dat de psychotherapeut zich had beperkt tot het plaatsen van kanttekeningen bij de rapportage van de GGZ-organisatie, aldus het CTG. De psychotherapeut was echter verder gegaan. Ook voldeed zijn rapport 'op een aantal belangrijke punten' niet aan de bovengenoemde vereisten. Zo waren diagnoses gesteld ten aanzien van zowel klaagster als de dochter louter op basis van de door de ex-partner aangeleverde stukken en gegevens (berisping). ${ }^{103}$ In een zaak waarover RTG Amsterdam op 28 maart 2017 oordeelde had een verpleegkundige, casemanager/coördinerend behandelaar, een verklaring afgegeven over een derde (klaagster, de moeder) waarvan hij wist dat die gebruikt zou worden in een

102 CTG 26 januari 2017, Stcrt. 2017, 6317.

103 CTG 12 april 2016, Stcrt. 2016, 20291. gerechtelijke procedure tussen de ouders van zijn patiënt, die aan een autistische stoornis lijdt. Volgens het RTG dient 'een behandelaar zich zeer terughoudend op te stellen bij het afgeven van verklaringen'. Dat geldt 'in nog sterkere mate bij het afgeven van verklaringen over derden'. De verpleegkundige had zich bewust moeten zijn van de zeer verstrekkende gevolgen die zijn verklaring kon hebben voor klaagster. Hij had zich bovendien moeten beperken tot de feiten en zich moeten onthouden van waardeoordelen. Door te verklaren dat klaagster 'verward' en 'overbelast door de gehele privé situatie' was en door de rechter te adviseren klaagster de toegang tijdelijk te ontzeggen had hij zich niet tot de feiten beperkt en had hij zich buiten zijn deskundigheidsterrein begeven (berisping). ${ }^{104}$

Klager had zich bij zijn werkgever ziek gemeld in verband met vermoeidheidsklachten. De bedrijfsarts stuurt hem door naar een gz-psycholoog voor nader psychologisch onderzoek. Deze rapporteert dat er bij klager geen sprake is van pathologie van betekenis, maar wel van malingering (simulatie) en aggravatie. De gz-psycholoog wordt verweten na het uitbrengen van het rapportage geen gesprek met klager te zijn aangegaan. RTG Amsterdam acht de klacht gegrond en legt een waarschuwing op. Daartegen komt de gz-psycholoog met succes op bij het CTG. Het CTG kan op basis van de Beroepscode voor psychologen van het NIP van 1 april 2007 niet vaststellen op grond waarvan de gz-psycholoog gehouden was om na het uitbrengen van zijn - voor klager onwelgevallige - rapportage met klager een gesprek aan te gaan over de uitkomsten van de rapportage en de invloed die dit op klager heeft gehad. De gz-psycholoog kon, na toevoeging van klagers reactie na inzage van de concept-rapportage, volstaan met het - conform zijn opdracht - uitbrengen van zijn definitieve rapportage aan de bedrijfsarts. ${ }^{105}$

Ook het correctierecht kan bij een, in casu psychiatrische, rapportage aan de orde zijn. Toetsingskader daarvoor is artikel 36 lid 1 Wet bescherming

104 RTG Amsterdam 28 maart 2017, Stcrt. 2017, 28742; vergelijk ook CTG 22 maart 2015, Stcrt. 2016, 17831.

105 CTG 18 mei 2017, Stcrt. 2017, 34381. 
persoonsgegevens en artikel 7.12 Richtlijn Medisch Specialistische Rapportage 2008, ${ }^{106}$ aldus het CTG in navolging van RTG Amsterdam. Kort gezegd had verweerder te weinig actie ondernomen om klager in staat te stellen het hem toekomende correctierecht uit te oefenen. Verweerder had nog opgeworpen dat in het rapport vrijwel geen feiten aan de orde kwamen die zich lenen voor het correctierecht. Volgens de Tuchtrechter doet deze zienswijze niet af aan de gehoudenheid om klager in staat te stellen het correctierecht uit te oefenen. 'Nádat het correctierecht is gerealiseerd, heeft de medisch rapporteur het recht het rapport al dan niet op basis daarvan aan te passen. Indien de rapporteur geen aanleiding ziet tot aanpassing, is het gebruikelijk dat de door betrokkene aangegeven correcties aan het rapport worden gehecht, zodat de opdrachtgever ook dan van beide zienswijzen kan kennisnemen. Het kan echter niet zo zijn dat een medisch rapporteur de betrokkene het correctierecht ontzegt omdat hij bij voorbaat meent dat uitoefening daarvan toch geen zin zal hebben.' Het RTG wijdt vervolgens enkele principiële beschouwingen aan het correctierecht: 'Het correctierecht ziet op de juistheid van de vaststelling en vastlegging van feiten. Dit recht is dus rechtstreeks bepalend voor de rechtspositie van betrokkene. Het in staat stellen van de onderzochte persoon om het correctierecht uit te oefenen is een elementaire taak en verantwoordelijkheid van de medisch rapporteur. Deze taak klemt temeer als het gaat om psychiatrische rapportages, waarbij betrokkenen niet zelden te kampen hebben met communicatie- en concentratieproblemen. Verweerder heeft zich onvoldoende rekenschap gegeven van de essentie van het correctierecht. Hij heeft het belang daarbij van klager, wiens arbeidsongeschiktheidsuitkering werd beoordeeld op basis van dit rapport, onvoldoende onder ogen gezien. Gegeven de relevante medische standaard heeft verweerder te snel tot onmogelijkheid geconcludeerd. Er stonden voor hem nog diverse logistieke wegen open die wel tot verschaffing van het correctierecht hadden kunnen leiden. Juist ook gegeven de bijzondere omstandig-

106 Inmiddels vervangen door de versie van april 2016. heden van het onderhavige geval, had hij niet mogen volstaan met de inspanningen waarop hij zich beroept.' De opgelegde waarschuwing wordt in hoger beroep bevestigd. Het CTG overwoog daarbij nog dat niet was gebleken dat klager afstand had gedaan van zijn correctierecht, zoals de psychiater had aangevoerd. Dat moet uitdrukkelijk gebeuren, aldus het CTG. ${ }^{107}$

\section{Bedrijfsartsen}

In de verslagperiode zijn de nodige uitspraken gedaan over het optreden van bedrijfsartsen. Gelet op de precaire positie die de bedrijfsarts in de relatie tussen werkgever en werknemer inneemt, wekt het geen verbazing dat deze nogal eens het doelwit van een tuchtklacht wordt. De jurisprudentie is vaak nogal casuïstisch, maar met name de lagere tuchtrechter voelt zich nog wel eens geroepen om enkele lijnen uit te zetten.

In een zaak waarover het CTG op 27 maart 2012 zijn oordeel uitbracht, zag een bedrijfsarts in totaal vier keer een vrouw met burn-outklachten. Elke keer verrichtte hij lichamelijk onderzoek, de eerste keer maakte hij ook een ECG. Volgens de tuchtrechter had de bedrijfsarts zich primair moeten richten op de burn-outklachten. Het door hem verrichte onderzoek was daartoe niet geschikt of aangewezen. Lichamelijk onderzoek kan nodig zijn bij burnoutklachten, maar moet dan wel in verhouding staan tot de klachten. Dat was hier niet het geval. ${ }^{108}$ In een andere zaak maakt een werknemer op zijn werk twee ernstige fouten. Hij wijt de fouten aan gebrek aan scherpte en concentratie. De werkgever stuurt hem door naar de bedrijfsarts. Deze laat de werkgever weten dat de werknemer inderdaad een concentratiestoornis heeft, maar dat deze stoornis geen verklaring kon vormen voor de gemaakte fouten. De arbeidsovereenkomst wordt daarna door de kantonrechter ontbonden. Volgens het CTG

107 CTG 26 januari 2017, ECLI:NL:TGZCTG:2016:246, Stcrt. 2017, 6316.

108 ECLI:NL:TGZCTG:2012:YG1945, Medisch Contact 2014, p. 378-379. 
behoort de beoordeling die de bedrijfsarts hier maakte niet tot diens deskundigheidsgebied. Het verwijst daarbij naar het Professioneel Statuut van de Bedrijfsarts waarin staat dat verzuimbegeleiding wel, maar claimbeoordeling en controle niet tot de taak van de bedrijfsarts horen. Hij krijgt een waarschuwing opgelegd. ${ }^{109}$

Diverse klachten waren aan de orde in de uitspraak van RTG Eindhoven van 2 november 2015, waarin een bedrijfsarts een berisping kreeg opgelegd. De bedrijfsarts had geen overleg gepleegd met de behandelend psychiater, die kenbaar had gemaakt dat klaagster niet belastbaar was, zonder onderscheid te maken tussen eigen werk en vervangende werkzaamheden. De bedrijfsarts had verder zijn rapport zonder overleg met klaagster aangepast. Hij had vragen van klaagster over het rapport niet beantwoord. Ten slotte had hij bagatelliserende opmerkingen gemaakt over de angst- en paniekstoornis van klaagster. ${ }^{110}$

Op 24 november 2015 overwoog het CTG dat het uitgangspunt is dat de Functionele Mogelijkheden Lijst (FML) met de werknemer wordt besproken, alvorens deze aan de werkgever wordt verstrekt. Het is evenwel niet noodzakelijk dat de werknemer met de inhoud van de FML instemt. In deze uitspraak was verder de probleemanalyse pas na ruim vier maanden (in plaats van de voorgeschreven zes weken) na de eerste ziekmelding opgesteld. De arts had gesteld dat de benodigde informatie niet eerder beschikbaar was, maar kon dit niet onderbouwen. De omstandigheid dat klager niet in zijn belangen is geschaad doet aan de tuchtrechtelijke verwijtbaarheid niet af (waarschuwing). ${ }^{111}$

Bij een werkneemster met suïcidale gedachten neemt de bedrijfsarts contact op met de huisarts en de crisisdienst. Dit leidt er uiteindelijk toe dat zij met een IBS wordt opgenomen. Wanneer hierover wordt geklaagd, stelt RTG Zwolle op 27 november 2015 voorop dat dit 'een voor de bedrijfsarts bijzondere situatie betrof'. Naar het oordeel van het Col-

109 CTG 10 april 2014, ECLI:NL:TGZCTG:2013:121, Medisch Contact 2014, p. 1228-1230.

110 RTG Eindhoven 2 november 2015, Stcrt. 2015, 47180.

111 ECLI:NL:TGZCTG:2015:326, Stcrt. 2015, 43658. lege getuigde het evenwel van goede zorg dat hij in een situatie waarin er een conflict van plichten was, de huisarts heeft gebeld om de zorg voor klaagster, als zij naar huis zou komen, te regelen. Hij heeft daarbij zijn geheimhoudingsplicht niet verder geschonden dan noodzakelijk. Ook heeft hij er goed aan gedaan de crisisdienst te bellen. Het in gang zetten van de IBS-procedure, die ook daadwerkelijk tot een opname heeft geleid, is de beslissing van de psychiater geweest en ondersteunt de inschatting van de bedrijfsarts dat er een reëel risico van gevaar voor klaagster was. ${ }^{112}$

De uitspraak van RTG Den Haag van 12 januari 2016 betrof een klacht van vier bedrijfsartsen tegen een andere bedrijfsarts, allen werkzaam voor een instelling die diensten verleent op het gebied van verzuimbegeleiding, preventie en re-integratie. Verweerster gaf functioneel, maar niet hiërarchisch, leiding aan een aantal (niet-medisch opgeleide) casemanagers. De hiërarchische leiding was in handen van een afdelingshoofd. Klagers stelden dat de casemanagers in diverse opzichten buiten hun boekje gingen (onder andere meer vragen stelden aan werknemers die zich hebben ziek gemeld, dan was toegestaan) en dat verweerster daartegen niet of onvoldoende optrad. Een en ander komt echter onvoldoende vast te staan en de klacht wordt daarom afgewezen. ${ }^{113}$

In een uitspraak van 18 januari 2016 van RTG Eindhoven werd de bedrijfsarts verweten bij het eerste contact in het kader van een ziekmelding te volstaan met een telefonisch consult in plaats van een regulier face-to-face-consult en dat de klager zich door het telefonisch consult overvallen heeft gevoeld. Klager had de klacht ingetrokken, maar de behandeling van de klacht wordt voortgezet om redenen aan het algemeen belang ontleend. Het College overweegt dat voor een eerste consult bij een werknemer met psychische problemen dertig minuten consulttijd wordt geadviseerd en dat het consult binnen twee tot drie weken na aanvang van het arbeidsverzuim dient plaats te vinden. Of mag worden vol-

112 ECLI:NL:TGZRZWO:2015:100.

113 ECLI:NL:TGZRSGR:2016:4, GJ 2016/29. 
staan met een telefonisch consult hangt af van de concrete omstandigheden van het geval. Van belang daarbij is of op deze manier voldoende anamnestische en objectief medische informatie wordt verkregen. Een telefonisch consult zal, net als een face-toface-consult, van tevoren gepland moeten worden, om te voorkomen dat de patiënt zich overvallen voelt. Niet gebleken is echter dat dit in casu heeft geleid tot een onvolledige anamnese. Voor het College is verder van belang dat verweerder zich rekenschap heeft geven van de beperkingen van een telefonisch consult, maar in het verloop van het consult en de verkregen informatie reden zag om met een telefonisch consult te volstaan (klacht afgewezen). ${ }^{114}$

In een zaak waarover het CTG op 28 januari 2016 zijn oordeel uitsprak, had in maart 2014 een bedrijfsarts bij een klager met rugklachten, voorafgaand aan het spreekuur, contact opgenomen met de huisarts van klager, om te verifiëren of er medische redenen waren voor het afzeggen van twee eerdere afspraken in de maand ervoor. In 2013 was er een arbeidsconflict geweest, maar dat was inmiddels opgelost. Volgens het CTG kon de bedrijfsarts zich voor het contact met de huisarts niet beroepen op een machtiging uit 2013, die bovendien in te algemene bewoordingen was gesteld. Verder werd de bedrijfsarts verweten onvoldoende te hebben doorgevraagd naar de aard en de ernst van de rugklachten en de beperkingen die klager daarvan ondervond. Hij bleef te lang vasthouden aan zijn werkhypothese dat de klachten van klager (weer) arbeidsgerelateerd waren (berisping). ${ }^{115}$

Een bedrijfsarts mag zich uiteraard niet alleen laten leiden door het belang van de werkgever. Dat was in casu ook niet het geval, zo besliste het CTG op 21 juni 2016. Het College was van oordeel dat de bedrijfsarts zich naar behoren had ingespannen om tot een juiste beoordeling van de arbeids(on)geschiktheid van klaagster te komen. Zij had ook meegedacht in het zoeken naar oplossingen voor de klachten. Dit heeft echter niet geleid tot een

114 ECLI:NL:TGZREIN:2016:5.

115 ECLI:NL:TGZCTG:2016:56, Stcrt. 2016, 5619. succesvolle re-integratie. Maar daaruit mag niet worden afgeleid dat de door de bedrijfsarts gevolgde route onjuist of onlogisch was. ${ }^{116}$

Op 3 mei 2016 legde RTG Den Haag een schorsing van drie maanden op aan een arboarts aan wie verschillende verwijten werden gemaakt. Hij voerde ten onrechte de titel van bedrijfsarts, hij had geen supervisie geregeld, hij bediende zich van een medische machtiging waaruit niet bleek welke informatie met welk doel werd opgevraagd, hij had zijn beroepsgeheim geschonden nu door zijn toedoen correspondentie tussen de arboarts en klager in het bezit van de werkgever is gekomen en hij had er geen blijk van gegeven een arts te zijn die zijn eigen regie voert en de grenzen van inmenging van de werkgever bewaakt. ${ }^{117}$ Over onvoldoende onafhankelijkheid wordt overigens vaker geklaagd, met wisselend succes. ${ }^{118}$

Ook in een andere zaak werd een arts verweten ten onrechte de titel bedrijfsarts te voeren in de terugkoppelingen naar de werkgever en in een door hem uitgebrachte rapportage. Hij verweert zich met de stelling dat de terugkoppelingen automatisch worden aangemaakt. Naar het oordeel van het CTG ontslaat dat de arts niet van de verantwoordelijkheid voor een juiste aanduiding van zijn titel in stukken die op zijn naam uitgaan. Dat de onjuiste aanduiding onder de rapportage het gevolg is van een nieuw automatiseringssysteem doet evenmin af aan de verantwoordelijkheid van de arts (waarschuwing). ${ }^{119}$

Onvoldoende uitvragen van klaagsters klachten met inachtneming van de Richtlijn psychische problemen uit 2007 en onvoldoende dossiervoering waren aan de orde in een zaak waarin RTG Eindhoven op 11 juli 2016 een bedrijfsarts een waarschuwing oplegde. De bedrijfsarts was onnodig snel en op

116 Stcrt. 2016, 34219.

117 Stcrt. 2016, 40545.

118 Zie bijvoorbeeld RTG Den Haag 1 maart 2016, ECLI:NL:TGZRSGR:2016:21; RTG Den Haag 8 november 2016, ECLI:NL:TGZRSGR:2016:113.

119 CTG 7 juli 2016, Stcrt. 2016, 40532. 
onvoldoende gronden tot het oordeel gekomen dat klaagster niet arbeidsongeschikt door ziekte was. ${ }^{120}$ In een zaak waarover het CTG op 4 oktober 2016 oordeelde, wordt de bedrijfsarts verweten dat hij zijn rapportage (over een accountmanager met burn-outklachten) eerder naar de werkgever dan naar de werknemer heeft gestuurd. De bedrijfsarts erkent dit, maar stelt dat de verzending daarvan onder de verantwoordelijkheid van de casemanager valt. Het CTG meent dat dat niet afdoet aan de eindverantwoordelijkheid van de bedrijfsarts. Toch wordt dit klachtonderdeel niet gegrond verklaard. Volgens het CTG verdient het, zeker bij een arbeidsconflict zoals in dit geval, aanbeveling dat een advies gelijktijdig aan de werkgever en de werknemer wordt gezonden, maar kan het nalaten daarvan de bedrijfsarts tuchtrechtelijk niet worden aangerekend, nu op dit punt geen in code, leidraad of richtlijn vastgelegde regel of aanbeveling bestaat. Twee andere klachtonderdelen, te weten het niet wegnemen van een onduidelijkheid in de rapportage en het opnemen van diskwalificerende opmerkingen over klager in het dossier ('manipulatief en dwingend'), worden wel gegrond geacht en leiden tot een berisping. ${ }^{121}$

In het kader van de beoordeling van de arbeidsongeschiktheid dient de bedrijfsarts zich uit te laten over de belastbaarheid van de betrokkene in het kader van haar eigen werk. Dat wordt niet anders als iemand boventallig is verklaard, aldus het CTG. Het College legt een waarschuwing op. ${ }^{122}$

Een schorsing voor de duur van een maand werd door het CTG opgelegd aan een arts aan wie meerdere verwijten werden gemaakt. Zo hanteerde hij ten onrechte de titel van bedrijfsarts en was de supervisie niet geregeld conform het NVAB Verenigingsstandpunt inzake de delegatie van taken door bedrijfsartsen in het kader van de sociaal-medische begeleiding uit 2004. Voor beide tekortkomingen was de arts al eerder berispt. Ook werd de arts verweten onvoldoende professioneel te hebben gehan-

120 Stcrt. 2016, 46088.

121 ECLI:TGZCTG:2016:306, GJ 2016/149.

122 CTG 24 november 2016, ECLI:NL:TGZCTG:2016:357, GJ $2017 / 24$. deld bij een dreigend conflict over de vraag of de partner bij het consult aanwezig kon zijn. Het spreekuurgesprek was uitgelopen tot een discussie op de gang. ${ }^{123}$ Over het onterecht voeren van de titel van bedrijfsarts wordt trouwens vaker met succes geklaagd. ${ }^{124}$

Inzage in respectievelijk afschrift van het dossier moet op grond van artikel 7:456 BW zo spoedig mogelijk worden gegeven. Volgens RTG Eindhoven had de aangeklaagde bedrijfsarts er persoonlijk op moeten toezien dat klager binnen een redelijke termijn (en niet pas een aantal maanden later) inzage in zijn dossier had verkregen en had hij hem niet mogen verwijzen naar de directeur van de arbodienst. Dat er mogelijk persoonlijke aantekeningen in het dossier voorhanden waren maakt dit niet anders, omdat de bedrijfsarts het dossier had kunnen schonen (waarschuwing). ${ }^{125}$

Door hetzelfde college werd een berisping opgelegd aan een bedrijfsarts vanwege structurele nalatigheid ten opzichte van klaagster. Hij had zich meermalen te passief opgesteld en een te beperkte taakopvatting gehanteerd. Ook de dossiervorming liet te wensen over. 'De indruk bestaat dat verweerder het belang van een volledige schriftelijke verslaglegging niet, althans onvoldoende, onderkent. ${ }^{126}$

Een basisarts die werkzaam is bij een arbodienst ziet op haar spreekuur een vrouw die zich met psychische klachten ziek heeft gemeld. Over de behandeling bij de psychotherapeut neemt zij in haar probleemanalyse op dat het ingezette behandeltraject niet adequaat is. De psychotherapeut dient hierover vervolgens een klacht in. Volgens RTG Eindhoven 15 maart 2017 had de arts in deze situatie contact moeten zoeken met de psychotherapeut. $\mathrm{Zij}$ is 'ten onrechte op de stoel van de bedrijfsarts gaan zitten' en heeft patiënte 'onnodig in verwarring gebracht

123 CTG 12 januari 2017, Stcrt. 2017, 3560.

124 Zie bijvoorbeeld CTG 7 juni 2016, ECLI:NL:TGZCTG: 2016:207 en het boven reeds aangehaalde CTG 7 juli 2016, Stcrt. 2016, 40532.

125 RTG Eindhoven 25 januari 2017, Stcrt. 2017, 14887.

126 RTG Eindhoven 25 januari 2017, Stcrt. 2017, 14843. 
en klagers behandelrelatie met patiënte onnodig in gevaar gebracht'. Het College waarschuwt de arts. ${ }^{127}$ In de zaak waarover het CTG op 16 mei 2017 oordeelde, ontving een bedrijfsarts in opleiding de Risico-inventarisatie en -evaluatie en bepaalde meetgegevens pas na twee jaar van de werkgever, ondanks herhaalde verzoeken daartoe. Zij hoefde echter niet uit te gaan van kwade trouw bij de werkgever en mocht menen dat de werkgever de informatie van ondergeschikt belang achtte, omdat de meetgegevens, zoals achteraf ook is gebleken, niet wezen op overschrijding van de vigerende normen. Ten aanzien van het verwijt dat zij een beroepsziekte had moeten melden, was het College met verweerster van oordeel dat in casu nog niet vaststond dat het om een beroepsziekte ging. Overigens overwoog de tuchtrechter dat bedrijfsartsen weliswaar wettelijk verplicht zijn beroepsziekten te melden bij het $\mathrm{NCvB}$, maar dat dit dient om de overheid ten behoeve van de beleids- en besluitvorming dienaangaande gegevens te verschaffen en dit geen betekenis heeft voor de aan klaagster te verlenen bedrijfsgeneeskundige zorg. ${ }^{128}$

\section{Verzekeringsartsen}

Ook verzekeringsartsen zijn nogal eens het doelwit van een tuchtklacht. In een zaak waarover het CTG op 12 maart 2015 oordeelde, had een verzekeringsarts een rapport uitgebracht over een vrouw die langdurig arbeidsongeschikt was vanwege RSIklachten. In niet mis te verstane bewoordingen kwam hij tot de conclusie dat niet haar werkzaamheden, maar haar persoonlijkheid en instelling tot het voortduren van haar klachten leidden. Volgens het CTG was zijn beoordeling niet deugdelijk onderbouwd en onevenwichtig. Mede door de stelligheid van zijn uitspraken kon bij klaagster de indruk van

127 Medisch Contact 2017, 22, p. 30-33.

128 CTG 16 mei 2017, ECLI:NL:TGZCTG:2017:141; Stcrt. 2017, 29907. een gebrek aan objectiviteit en onafhankelijkheid ontstaan. $^{129}$

Op 1 december 2015 oordeelde het CTG dat het standpunt dat een verzekeringsarts niet mag oordelen over een medisch-specialistische rapportage onjuist is. De verzekeringsarts was het niet eens met de bevindingen van een psychiater die een rapport had uitgebracht in een rechterlijke procedure tegen de afwijzing van een Wajong-uitkering. Volgens het CTG is het juist de taak van een verzekeringsarts om op basis van eigen onderzoek en alle beschikbare medische gegevens en rapporten zich een zelfstandig oordeel te vormen over de belastbaarheid van de betrokkene. ${ }^{130}$

In een zaak waarover het CTG op 7 juli 2016 oordeelde, verweet klaagster de verzekeringsarts dat zij geen eigen deskundigenoordeel had gegeven, maar was blijven staan achter een eerder rapport van een psychiater. Uit de rapportage van de verzekeringsarts bleek echter dat zij diens conclusie niet onverkort had overgenomen, maar deze had aangevuld op basis van haar eigen bevindingen en onderzoek. Het beroep tegen de afwijzing van de klacht in eerste aanleg wordt verworpen. ${ }^{131}$

In diverse uitspraken wordt de rapportage van de verzekeringsarts getoetst aan het eerder besproken vaste, vijf criteria omvattende, stramien dat het CTG voor medische rapporten heeft ontwikkeld, waarbij de vakkundigheid en zorgvuldigheid waarmee het onderzoek is verricht, volledig worden getoetst en de conclusie marginaal. ${ }^{132}$ In zijn beslissing van 13 januari 2016 was het CTG van oordeel dat de conclusie dat klaagster voltijds belastbaar was, onbegrijpelijk en in redelijkheid niet te trekken was. Waar het RTG nog had volstaan met een waarschuwing, wordt de arts in hoger beroep berispt, waarbij mede

129 ECLI:NL:TGZCTG:2015:81; Medisch Contact 2015, p. 684-686.

130 Stcrt. 2015, 45305.

131 ECLI:NL:TGZCTG:2016:241.

132 CTG 30 januari 2014, ECLI:NL:TGZCTG:2014:17, TvGR 2014/18, m.nt. J.C.J. Dute. 
wordt overwogen dat hij onvoldoende blijk heeft gegeven van enige reflectie op zijn tekortkoming. ${ }^{133}$ Een basisarts, werkzaam voor het UWV, had een medisch en een niet-medisch rapport opgemaakt. Het niet-medische rapport was bedoeld voor overdracht van gegevens aan niet-medici, belast met de uitvoering van in dit geval de Ziektewet. Daarin had zij vermeld dat klager zich arbeidsongeschikt had gemeld met 'hartklachten'. De daartegen gerichte klacht achtte RTG Den Haag gegrond, evenwel zonder oplegging van een maatregel. ${ }^{134}$ De supervisor van de basisarts, die het rapport akkoord had bevonden en waartegen eveneens een procedure was ingesteld, kreeg wel een waarschuwing opgelegd. Daarbij was van belang dat hij er geen blijk van had gegeven het onjuiste van zijn handelen in te zien. ${ }^{135}$ In een andere zaak had de verzekeringsarts, in zijn rapport voor een aanvraag in het kader van de Wet maatschappelijke ondersteuning, het ziektebeeld van klager vermeld, alsmede de door klager gebruikte medicatie. De daartegen gerichte klacht is gegrond, nu de arts slechts de beperkingen had moeten weergeven. Ook de rapportage vertoonde gebreken. RTG Eindhoven legt een waarschuwing op. ${ }^{136}$

\section{BMA-artsen}

In de verslagperiode zijn verschillende uitspraken gedaan over het handelen van artsen die zijn verbonden aan het Bureau Medische Advisering (BMA). Het is hun taak medisch advies uit te brengen als de Immigratie- en Naturalisatiedienst (IND) het BMA daar in een vreemdelingenrechtelijke procedure om verzoekt. Zij begeven zich daarbij op het terrein van

133 CTG 10 december 2015, ECLI:NL:TGZCTG:2015:369; Stcrt. 2016, 752. Zie ook CTG 19 januari 2017, ECLI:NL:TGZCTG:2017:42 (arts kon in redelijkheid tot zijn conclusie komen); RTG Amsterdam 10 november 2015, ECLI:NL:TGZRAMS:2015:97, Medisch Contact 2017, 9, p. 34-36; RTG Eindhoven 6 juni 2016, Stcrt. 2016, 46087.

134 RTG Den Haag 14 juni 2016, Stcrt. 2016, 64883.

135 RTG Den Haag 30 augustus 2016, Stcrt. 2016, 64889.

136 RTG Eindhoven 6 juni 2016, Stcrt. 2016, 46087. de individuele gezondheidszorg en hun handelen wordt getoetst aan de tweede tuchtnorm. Dat bestuursrechtelijk kan worden opgekomen tegen de uitzettingsbeslissing van de staatssecretaris, waarin ook eventuele gebreken van het BMA-advies aan de orde kunnen worden gesteld, "is van belang voor het tuchtcollege doch louter als achtergrondinformatie.'. ${ }^{137}$

'Het college stelt voorop dat het niet tot taak heeft het in Nederland geldende vreemdelingenrecht te formuleren of te toetsen', zo valt te lezen in een uitspraak van het CTG van 21 juni 2016. ${ }^{138}$ Ter beoordeling staat slechts of de BMA-arts zich bij zijn advisering heeft gehouden aan de voor hem geldende professionele standaard, zoals vervat in de Wet BIG, de regeling van de geneeskundige behandelingsovereenkomst, de Wet bescherming persoonsgegevens en het Protocol Bureau Medische Advisering van de IND van oktober 2010. De rapportage wordt voorts getoetst aan het eerder besproken, vaste beoordelingskader voor medische adviezen. Daarvan geven wij enkele voorbeelden.

In een zaak tegen een als BMA-arts werkzame verzekeringsarts, die over een periode van drie jaar een zestal adviezen had uitgebracht over een jong kind, oordeelde RTG Den Haag dat de arts was tekortgeschoten ten aanzien van onderzoek, feitengaring, vraagstelling en conclusie. Daardoor had zij het gevaar van een medische noodsituatie bij terugzending naar het land van herkomst onderschat. In hoger beroep bleef van het oordeel van het RTG niet veel over. Het CTG plaatst slechts bij één advies een aantal kanttekeningen, die door de arts zijn erkend. De in eerste aanleg opgelegde waarschuwing blijft daarom in stand. ${ }^{139}$

Een door het BMA ingeschakelde psychiater kreeg van RTG Amsterdam een berisping opgelegd, omdat zijn rapportage niet voldeed aan de vereiste criteria. Hij was op onvoldoende gronden tot de conclusie gekomen dat bij klager geen sprake was van PTSS en dat deze simuleerde. Het CTG verwerpt

137 CTG 8 maart 2016, Stcrt. 2016, 13871.

138 ECLI:NL:TGZCTG:2016:228.

139 CTG 7 juni 2016, ECLI:NL:TGZCTG:2016:208, Stcrt. 2016, 30960. 
het beroep. Dat de psychiater zijn werkwijze inmiddels heeft aangepast, leidt niet tot een lichtere maatregel. ${ }^{140}$

In een procedure tegen een als BMA-arts werkzame verzekeringsarts wordt het boven geschetste toetsingskader nog wat verder uitgewerkt. Ten eerste mag een BMA-arts in beginsel uitgaan van de door de vertrouwenspersoon verstrekte informatie, tenzij evident is dat adviezen van een bepaalde bron structureel klachten oproepen of structureel sprake is van innerlijk tegenstrijdige adviezen. Nader onderzoek is voorts nodig wanneer de arts twijfelt of moet twijfelen aan de juistheid van individuele informatie van de vertrouwensarts. Ten tweede wordt van de BMA-arts niet verlangd dat hij onderzoek doet naar de individuele toegankelijkheid van de behandeling. Dit komt anders te liggen als in een individueel geval het dossier, zoals hem dat ter beschikking staat, gerede twijfel moet oproepen over de effectiviteit van de in het algemeen beschikbare behandeling of zorg. ${ }^{141}$

Klaagster stelt in beroep dat de BMA-arts, in casu een bedrijfsarts, gehouden was om te beoordelen wat de medische gevolgen zouden zijn van een eventuele verwijdering en of terugkeer mogelijk zou leiden tot het ontstaan van een medische noodsituatie. Klaagster verwijst daarbij naar het Protocol Bureau Medische Advisering. Volgens het CTG diende de arts op grond van dat protocol echter uitsluitend een antwoord te geven op de vraag of het staken van de behandeling op korte termijn tot een medische noodsituatie zou kunnen leiden. Dat had de arts in zijn advies gedaan en daarom slaagt het beroep tegen de ongegrondverklaring van de klacht in eerste aanleg niet. ${ }^{142}$

Op 17 mei 2016 verenigt het CTG zich met de volgende overwegingen van het College in eerste aanleg. 'Het College stelt voorop dat de geldende rechtspraak van het Centraal Tuchtcollege voor de Gezondheidszorg inhoudt dat de zorgvuldigheid die een BMA-arts bij het uitbrengen van een medisch advies jegens een aanvrager van een verblijfsvergunning (dan wel uitstel van vertrek) heeft te betrachten meebrengt dat de BMA-arts zo mogelijk nader onderzoek moet verrichten, indien in een individueel geval de gegevens in het dossier van de aanvrager aanleiding moeten zijn gerede twijfel te hebben over de effectiviteit voor de aanvrager van de in het algemeen verkrijgbare medische behandeling in het land van herkomst of bestemming. Dit uitgangspunt brengt niet mee dat, in het geval waarin vaststaat dat de medicijnen waarop de aanvrager is ingesteld niet voorhanden zijn in het land van herkomst of bestemming, maar ter plaatse wel alternatieve medicatie (of behandeling anderszins) beschikbaar is, de BMA-arts behoort te onderzoeken en zeker te stellen dat die alternatieve medicatie (of behandeling anderszins) daadwerkelijk effectief zal zijn voor de behandeling van de aanvrager. Dit kan anders zijn als uit het dossier blijkt van medische feiten die een aanwijzing vormen dat de alternatieve medicatie (of behandeling anderszins) niet of onvoldoende effectief zal zijn.' ${ }^{143}$

Naar het oordeel van het College hoefde de arts in casu geen onderzoek te doen naar de in het betreffende land aanwezige alternatieven, nu uit de voorhanden zijnde medische informatie over klager niet van een contra-indicatie was gebleken. Dat later nieuwe informatie over klager bekend is geworden doet daar niet aan af, nu verweerder bij het opstellen van het advies daar niet over beschikte. Voorts wordt overwogen: 'De stelling van klager, dat verweerster een specialist had moeten raadplegen, omdat zij zelf niet over de benodigde kennis beschikt om te kunnen beoordelen of behandeling in het land van herkomst geschikt is, treft geen doel. Als uitgangspunt heeft te gelden dat de arts de kennis en de kunde bezit, althans wordt geacht die te bezitten, om aan de hand van de beschikbare medische gegevens te beoordelen of er in zijn algemeenheid behandeling mogelijk is in E. voor de aandoening die klager heeft. Van omstandigheden die tot

140 CTG 10 september 2015, ECLI:NL:TGZCTG: 2015:288.

141 CTG 8 maart 2016, Stcrt. 2016, 13871.

142 CTG 21 juni 2016, ECLI:NL:TGZCTG:2016:231.

143 Verwezen wordt naar ECLI:NL:TGZCTG:2014:60 en ECLI:NL:TGZCTG:2015:176. 
een ander oordeel aanleiding zouden kunnen geven, is niet gebleken.' ${ }^{144}$

\section{Beschouwing}

Hoewel, zoals in de inleiding vermeld, het aantal ingediende tuchtklachten niet exponentieel lijkt toe te nemen, geldt dat wel voor de hoeveelheid interessante jurisprudentie. Daarbij valt op dat de discussies over ontvankelijkheid en overige procesrechtelijke vraagstukken ondanks (of dankzij)? de hoeveelheid jurisprudentie niet afnemen. Voor wat betreft de tweede tuchtnorm ontbreekt nog steeds een heldere en consistente lijn en is niet duidelijk hoe het criterium 'in de hoedanigheid van BIG-geregistreerde' en het zogenoemde weerslagcriterium zich tot elkaar verhouden en/of in het algemeen aan beide criteria moet worden voldaan om tot ontvankelijkheid te concluderen.

Voor wat betreft procesrechtelijke vraagstukken valt de beperkte uitleg op die het CTG geeft aan artikel 73 lid 7 jo. artikel 65 lid 10 Wet BIG als het gaat om het intrekken van een hoger beroep; anders dan bij de ontvankelijkheidsdiscussie neemt het CTG hier een behoudend standpunt in.

Ten aanzien van de reikwijdte van het tuchtrecht lijkt het erop dat ook daar de inhoudelijke toetsing breder lijkt te worden getrokken dan in het verleden. Zo wordt de in het ziekenhuis werkzame arts (mede)verantwoordelijk geacht voor de inzage in en het bewaren van dossiers en voor de wijze van afwikkeling van aansprakelijkheidsclaims.

Adequate dossiervoering vinden tuchtcolleges steeds van groot belang, met name ook als wordt afgeweken van een richtlijn of als sprake is van een experimentele behandeling in welke gevallen er een extra zware dossierplicht geldt.

Bij samenwerkingsvraagstukken valt op dat de afbakening van de verantwoordelijkheden tussen enerzijds artsen en anderzijds BIG-geregistreerde beroepsbeoefenaren die geen arts zijn, zoals verpleegkundigen, verloskundigen of arts-assistenten (niet) in opleiding, nog steeds regelmatig tot tucht- rechtelijke verwijtbaarheid leidt omdat het aan goede afspraken of de juiste uitvoering daarvan ontbreekt. Bij de inschakeling van hulppersoneel of waarnemers geldt dat het bij hen soms ontbreekt aan bevoegdheid en/of bekwaamheid om de betreffende handeling of beoordeling te verrichten, hetgeen leidt tot tuchtrechtelijke aansprakelijkheid van degene die hen inschakelt of voor wie wordt waargenomen.

De praktijk worstelt verder nog steeds met het hoofdbehandelaarschap en de (zware) eisen die het CTG daaraan stelt.

De tuchtrechtelijke jurisprudentie inzake geneeskundige verklaringen laat een consistent beeld zien van ieder jaar min of meer dezelfde verwijtbaarheden; de uitspraken van tuchtcolleges lijken geen preventief effect te hebben. Dit roept de vraag op of het opleggen van zwaardere maatregelen zou helpen. Voor wat betreft de beoordeling van medische rapportages biedt het in 2014 op onderdelen aangepaste kader van het CTG een duidelijke kapstok.

Over bedrijfs- en verzekeringsartsen wordt relatief vaak geklaagd. Een aantal uitspraken gaat over het ten onrechte voeren van de titel bedrijfsarts. Basisartsen die in deze sector werken lijken regelmatig tuchtrechtelijk in de problemen te komen.

Ten slotte valt op dat het aantal zware tuchtmaatregelen eerder toe dan af lijkt te nemen. Met name bij het voorkomen van fraude en/of seksueel grensoverschrijdend gedrag wordt ten minste een schorsing, maar nog veel vaker een doorhaling opgelegd. 